\title{
Germanic Neopaganism - A Nordic Art-Religion?
}

Aesthetic imaginaries in stories, paintings, film, and music, ranging from Wagnerian opera to contemporary black metal, Viking metal, Pagan metal, and neofolk music have had a strong impact on Asatru as well as on popular images of Nordic myth and religion. They have even shaped academic contributions to the discourse of Nordic myth. In spite of their professed commitment to academic knowledge, many Asatruers mention fictional books as their main sources of inspiration and knowledge of Nordic religion. Furthermore, Asatruers often perceive their own religious practices as aesthetic activities. All of this can be attributed to the specific appeal of art and fiction in modernity. They are modes that bring to life the historical past, speak to the senses, and allow emotional identification. Artworks can create a sense of identity and community (be it national or otherwise) which goes beyond a purely fact-oriented and intellectual level; they allow the creation of coherent worlds beyond the meager and scattered, often contradictory primary sources. This widespread popularity has turned certain aesthetic genres - popular literature and music in particular into privileged media in Asatru's path toward respectability. They are media Asatruers themselves use to disseminate their thoughts and connect themselves with broader ideas about culture and identity. In addition, they are mainstream media that provide material for the construction of Heathen religion. At the same time, aesthetic approaches lend themselves to a more playful, individualized manner of conducting a spiritual life. Contemporary Neopagan religions in particular tend to perceive their spirituality as a creative process, and to assign art, music, literature, and performance spiritual qualities.

All of these observations can be contextualized within a concept that originated around 1800 in German Romanticism: the concept of art-religion (Kunstreligion). Generally speaking, and perhaps surprisingly for many, it is in modernity rather than in ancient or pre-modern times that religion and art, the spiritual and the aesthetic, appear to be most closely related. 19thcentury thought, and particularly that of German idealist theologian Friedrich Schleiermacher (1768-1834), conceptualizes religion as a realm of aesthetic experience. Schleiermacher was the first to tie religion explicitly to emotion, experience, interiority, and the private sphere, the fields in which modern art is located as well. At the same time, art is increasingly assigned religious functions: the artwork is seen as capable of creating transcendent meaning; the process of artistic creation is perceived as a religiously inspired act; the artist is

(C) KONINKLIJKE BRILL NV, LEIDEN, 2016 | DOI 10.1163/9789004309517_011

This is an open-access article distributed under the terms of the Creative Commons Attribution-

NonCommercial 3.o. Unported (CC BY-NC 3.o) License, http://creativeccommons.org/licenses/by-nc/3.969004309517 
assigned the role of a prophet, priest, or savior; and art itself is celebrated in

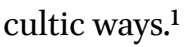

Germanist Heinrich Detering has recently argued that the historical precondition for this constellation of art-religion, for the adoption of religious functions in art and vice versa, is a differentiation of the spheres of art and religion in modern society into two clearly distinguishable realms. It is the perception of, or a conscious suffering from, this differentiation that leads to the nostalgic yearning for a restoration of an imagined lost unity, the emphatic invocation of a future unification or a synthesis of both. ${ }^{2}$ What is compelling for our context is the fact that this art-religion paradigm and the discourse on Nordic myth originate in the same era and in the same intellectual constellation, and that they are so closely entwined from the beginning. ${ }^{3}$

This chapter demonstrates that the rediscovery of Norse mythology and its functionalization for various national, cultural, and religious renewals in different countries (most prominently Germany and the Nordic countries) is set within an art-religious context. It concludes that Germanic Neopagan beliefs and practices, as well as the discourses from which they emerge, to which they contribute and which have been at the center of the previous chapters, are best understood as the popularization of the discourse of Nordic myth, as well as of art-religion itself and its transformation into alternative spiritual practice.

\section{Nineteenth Century Concepts of Germanic Art-Religion}

If we look at the Romantic context in which the German and Scandinavian Romantic revival of Norse myth and the literary discovery of the Eddic lays

1 For a summarizing discussion of art-religion see Heinrich Detering, "Was ist Kunstreligion? Systematische und historische Bemerkungen," in Kunstreligion. Ein ästhetisches Konzept der Moderne in seiner historischen Entfaltung. Vol. I (Der Ursprung des Konzepts um 180o), ed. Albert Meier, Allesandro Costazza, and Gérard Laudin (Berlin: De Gruyter, 2011) and "Religion," in Handbuch Literaturwissenschaft. Vol. I (Gegenstände - Konzepte - Institutionen), ed. Thomas Anz (Stuttgart/Weimar: Metzler, 2007).

2 Cf. "Was ist Kunstreligion?" and "Religion," as well as Williamson, The Longing for Myth in Germany, 15. He argues not only that the discourse on myth emerged in secular institutions, mainly in scholarship, art, and literature, but that its claim to sacred status and - we might add - the formation of new religions based on such myths have their origins in such secular institutions as well.

3 This might also have to do with the fact that, since the Renaissance, the arts appear as the realm where the depiction of non-Christian myth is permitted. We might even go so far as to say that one of the main sources for Nordic myth, Snorri's Edda, follows a similar pattern, as it is written as a reference book for poets. 
were set, we encounter the same authors who also laid the ground for the modern sacralization of art. During his twenty years in the Danish court, German writer Friedrich Gottlieb Klopstock (1724-1803) developed a vision of the artist as a seer-priest, and of religious texts as works of poetry. ${ }^{4}$ During this time he made use of the first translations of the Eddic lays. He fused them with Ossianic elements in order to create an art form inspired by then-current conceptions of 'national' mythology. For Johann Gottfried Herder, who further developed this approach, the search for a national mythology was first and foremost an aesthetic endeavor as well, or more precisely, a literary one. For him, folk songs in particular represented the purest embodiment of national folk poetry. His essayistic dialogue "Iduna, oder der Apfel der Verjüngung" (Iduna, or the Apple of Rejuvenation"), which appeared in Friedrich Schiller's monthly literary journal Die Horen in $1796,{ }^{5}$ outlines the pros and cons of employing the newly available Eddic myths for a renewal of German poetry as a didactic dialogue. It took up the then-recent fashion of Bardic poetry in the spirit of Macpherson's Ossian and melded it with Herder's own ideas about the unity of myth, landscape, and nation. However, in constrast to many of his contemporaries, Herder insisted on the fundamental difference between the "soft, sad sentiments" of the Celts and the deed-oriented songs of the Nordic peoples, with whom he identified the Germans. ${ }^{6}$ Herder's targeted course was clearly literary and aesthetic, but in a way which imbues fictional narrative with a sacral aura. He saw literature as the privileged medium conveying transcendent universal truth and meaning. In order to be effective, understandable, vital, capable of development, and thus apt for modernity, universal ideas need forms that are organically connected to the past (the childhood of the nation) and an equally organically developed language with roots in national myth. Herder hoped to find compensation for the lack of "a mythology rooted in their own mentality and language" 7 and the lack of a developed heroic poetry in the "mythology of

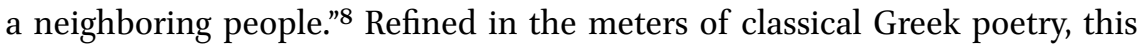
mythology would lay the foundations for the rejuvenation of national literature and culture. Herder formulated two principles that were to have great impact on the future development of theories of myth and nation both in Germany and abroad. One of these principles was the notion of a Kulturnation, a nation built on an organic culture and not defined by a state apparatus. This idea was to influence German nationalism in the 19th century and laid the

4 Detering, "Religion," 391f, see also "Was ist Kunstreligion?" 15.

5 Johann Gottfried Herder, "Iduna, oder der Apfel der Verjüngung," Die Horen 5, no. 2 (1796).

6 Ibid., 30 [26].

7 Ibid., 2 [8]: "eine in ihrer eigenen Denkart und Sprache entsproßene Mythologie."

8 Ibid., 8 [14]: "Mythologie eines benachbarten Volkes." 
foundation for the formulation of a national art-religion in other countries. The notion of a Kulturnation implied the assumption that Scandinavian mythological texts actually stem from the same sources as the lost German mythology, and can thus be employed to reconstruct a German literary and mythical national heritage.

Herder's impact on the rediscovery of Norse mythological themes in Germany, as well as in Anglo-American thought and the Gothic and Nordic revivals of Scandinavian Romanticism, can hardly be over-estimated, although the reception of his work in the Nordic countries and in English-language contexts is as yet under-researched. ${ }^{9}$ What is clear is that the aesthetic works of the Nordic or Gothic revival in Swedish and Danish Romanticism provided an arsenal of literary topoi, ideas, and images of Norse mythology and religion which spread widely and became firmly established, not only in their respective national imaginations but also internationally. In Denmark as well as in Sweden, the Romantic literary movements were set in the context of the national defeats connected with the Napoleonic and other early 19th-century wars. Also here, the turn to literature as a privileged medium to create access to a national heroic past and thus a feeling of unity and identity became an important part of the attempt to consolidate national identities in times of political crisis and military decline. It inspired the popularizations of medieval materials in poetry, drama, and later, in painting as well. Among them were the immensely popular heroic historical dramas by the Dane Adam Oehlenschläger (1779-1850). With his early poem "Guldhornene" ("The Gold-Horns," 1802), this author had previously provided a poetic myth of national loss and rebirth through the search for roots in a mythological past still living in Danish soil, nature, and rural people. ${ }^{10}$ Another Danish writer, Nikolai Frederik Severin Grundtvig (1783-1872), succeeded in firmly tying poetical imaginaries of Nordic deities to a sense of a national Christian identity. ${ }^{11}$ As a result, Nordic myth

9 First reflections on the topic can be found in Bernd Henningsen, "Johann Gottfried Herder and the North. Elements of a Process of Construcion," in Northbound. Travels, Encounters, and Constructions 1700-1830, ed. Karen Klitgaard Poulsen (Aarhus: Aarhus University Press, 2007).

10 Adam Oehlenschläger, Digte (Copenhagen: Andreas Seidelin, 1803).

11 See in particular Nikolai Frederik Severin Grundtvig, "Nordens Mytologi, eller Udsigt over Eddalæren for dannede Mænd, der ei selv ere Mytologer," in N.F.S. Grundtvig, Verker i udvalg, ed. Georg Christensen and Hal Koch (Copenhagen: Gyldendal, 1940 [1810]). Cf. also Lars Lönnroth, "The Academy of Odin. Grundtvig's Political Instrumentalization of Old Norse Mythology," in Idee - Gestalt - Geschichte. Studien zur europäischen Kulturtradition. Festschrift für Klaus von See, ed. Gerd Wolfgang Weber (Odense: Odense University Press, 1988); Lundgreen-Nielsen, "Gundtvig's Norse Mythological Imagery." 
came to be seen as such an integral part of the Danish nation, culture, and even mainstream Protestant religion throughout the 19th and 2oth centuries that a need for the foundation of Asatru groups did not arise until the late $1990{ }^{12}{ }^{12}$ In Sweden, poems by Erik Gustaf Geijer (1783-1847) established the Viking and the independent peasant as archetypical images of the great Swedish nation. ${ }^{13}$ The single most influential text on an international scale was an epic poem by Esaias Tegnér (1782-1846) about the hero Frithiof, which was loosely inspired by an Icelandic saga. ${ }^{14}$ Frithiofs Saga was soon translated into English and German and became widely popular in both countries as well as in Scandinavia. It shaped ideas about Nordic heroism, which was depicted as an equivalent of modern bourgeois European ideals, and claimed a fundamental affinity between Nordic pagan and Christian values. 15

The Nordic aesthetic revival in the Scandinavian countries provided sacralized images of Nordic history that were reconcilable with the sense that Lutheranism was the national religion. The implicit logic of this idea is similar to that of the German case: while Mediterranean culture and Greek and Roman antiquity are alleged to hold a strong appeal for the Northerners, they should nevertheless be perceived as ultimately foreign. Catholicism is then aligned with these 'foreign,' 'Southern' Greek and Roman traditions, while Lutheran Protestantism is perceived to be a continuation of the Nordic traditions celebrated in Romantic poetry. A similar argument was made for the Church of England in the mid-19th century, as the following quote by the novelist and historian Charles Kingsley shows:

I say that the Church of England is wonderfully and mystically fitted for the souls of free Norse-Saxon race; for men whose ancestors fought by the side of Odin, over whom a descendant of Odin now rules. ${ }^{16}$

Also in England, knowledge about and imagery of Norse gods, Anglo-Saxon, and Viking culture were disseminated in literary works, for example those by

12 Cf. Schnurbein, Religion als Kulturkritik, 211f.

13 For Oehlenschläger's and Geijer's debt to Macpherson's Ossian cf. Bo Jansson, "Nordens poetiska reception av Europas reception av det nordiska," in The Waking of Angantyr. The Scandinavian Past in European Culture - Den nordiske fortid $i$ europæeisk kultur, ed. Else Roesdahl and Preben Meulengracht Sørensen (Aarhus: Aarhus University Press, 1996).

14 Esaias Tegnér, Frithiofs saga, ed. Åke K.G. Lundquist, 7 vols., vol. 4, Esaias Tegnérs samlade dikter (Lund: Gleerup, 1986).

15 Cf. Wawn, The Vikings and the Victorians, 117-141.

16 Quoted in ibid., mottos. 
Walter Scott. His The Pirate (1821) borrowed heavily from saga literature, ${ }^{17}$ and Ivanhoe "inspired a whole generation with a vision of Saxon freedom and honesty." ${ }^{18}$ Most important for the spread of Nordic myth and heroic poetry in England was William Morris' retelling of the Norse Nibelungen material. ${ }^{19}$ A plethora of late 19th-century Viking novels, including Eric Brighteyes (1891) by H. Rider Haggard, projected a vision of the "white race's" imperial conquest onto the Vikings ${ }^{20}$ - a vision which still reverberates in 2oth century English and American literary and filmic Viking imagery, and which inspired some of the early Asatruers in the United States.

Morris, along with laterViking enthusiasts, followed another German source of inspiration: Richard Wagner. In his The Ring of the Nibelung (first staged in Bayreuth in 1876), the Nordic constellation of art-religion reached its climax. Anti-clerical in outlook, Wagner's work popularized the idea that a Pagan Germanic religion that was preserved in the far north should form the basis for the national renewal of Germany, and he assigned the artist the role of the herald of this ancient, yet new message. Wagner was the first German artist to make use of medieval Scandinavian sources of the Nibelungen material, because he found them to be more original and thus apt to express myth's timeless character than the German Nibelungenlied, which is located in a courtly and Christian setting. ${ }^{21}$ He drew on contemporary scholarship in German philology, including Jacob Grimm's "Deutsche Mythologie," in order to give his ideas on myth and art a foundation in canonical themes and motives. In his theoretical texts, particularly in The Artwork of the Future, ${ }^{22}$ he developed a revolutionary political vision: a "political economy of love," based on the revolutionary notion of the Volk itself as the artist who was to bring about

17 David M. Wilson, "The Viking Age in British Literature and History in the Eighteenth and Nineteenth Centuries," in The Waking of Angantyr. The Scandinavian Past in European Culture-Den nordiske fortid i europceisk kultur, ed. Else Roesdahl and Preben Meulengracht Sørensen (Aarhus: Aarhus University Press, 1996), 64f.

18 Horsman, Race and Manifest Destiny, 40.

19 Wilson, "The Viking Age in British Literature and History," 67; Wawn, The Vikings and the Victorians, 245-281; Paola Spinozzi, "The Topos of Ragnarök in the Utopian Thought of William Morris," in Eddische Götter und Helden. Milieus und Medien ihrer Rezeption. Eddic Gods and Heroes. The Milieux and Media of Their Reception, ed. Katja Schulz (Heidelberg: Winter, 2011).

20 Cf. Wawn, The Vikings and the Victorians, 332-335.

21 For Wagner's treatment of the Nordic sources see for example Böldl, Der Mythos der Edda, 271-277.

22 Richard Wagner, "The Art-Work of the Future," in The Art-Work of the Future. Richard Wagner's Prose Works (London: Keegan Paul, Trench, Trübner, 1895 [1849]). 
the "new myth." Wagner certainly supported Romantic ideas of the unity of nature, humanity, myth, and art as the basis of the people, for example, in his description of art as a process by which nature "grows conscious of herself in man, the artist."23 The Volk for Wagner was constituted through a shared need. Only those who felt this need belonged to the Volk, while the "egoists," basking in luxury and empty fashionable aestheticism, were excluded. Consequently, the artist, who is to give the eternal myth its appropriate form to counter such present "need," is the one who feels and embodies this need most strongly.

Wagner's model for the renewed unity of Volk and art is Greek tragedy in its idealized version as promoted by German classicists such as Johann Joachim Winckelmann (1717-1768) and Friedrich Schiller (1759-1805). For him, it appears as an art form which emerged directly from the people, celebrated its unity in a simultaneously religious and artistic act, and united all the individual arts including song, poetry, dance, and visual art in a grand Gesamtkunstwerk (total art work). In contrast to Schiller and Winckelmann however, Wagner did not consider Greek myth to be the appropriate form for the new holistic artwork that was meant to unite the German people of his time. Instead of using Greek myth as the basis for his work, Wagner merged ideas about a 'pure' Christianity (i.e., uncorrupted by church institutions) with Nordic myth. The result is an immanent concept of religion centered on "human nature in its naked essence, before it had been corrupted by succeeding layers of religion, history, and convention."24 Wagner took his inspiration from Ludwig Feuerbach's (1804-1872) critical theory of religion. The philosopher saw the essence of human nature in "material activity (Handlung)" rather than abstract concepts. He despised Christianity, considering it as a decline from the ancient Greek polytheism, which, due to its connection between humans and nature, had furthered the development of art and science. ${ }^{25}$ Feuerbach and Wagner thus laid the foundation for later ideas about pre-Christian religions as religions of deed (Tatreligion), discussed in Chapter 3. Feuerbach's theory also provided Wagner with a justification for his anti-Semitic critique of both religion and contemporary art. ${ }^{26}$ Wagner's attitude toward Jews, along with his

23 Ibid., 70; "Das Kunstwerk der Zukunft," in Sämtliche Schriften und Dichtungen, ed. Richard Wagner (Leipzig: Breitkopf und Härtel, 1911 [1849]).

24 Williamson, The Longing for Myth in Germany, 196.

25 This argument is developed by Williamson, ibid., 193.

26 Cf. Lincoln, Theorizing Myth, 57f; Williamson, The Longing for Myth in Germany, 205; Hildegard Chatellier, "Wagnerismus in der Kaiserzeit," in Handbuch zur 'Völkischen Bewegung' 1871-1918, ed. Uwe Puschner, Walter Schmitz, and Justus H. Ulbricht (Munich etc.: K.G. Saur, 1996), 577 and 583 . 
fierce anti-Semitic diatribes, especially in his infamous essay "Das Judentum in der Musik" ("Judaism in Music," 1850), ${ }^{27}$ have given rise to much controversial discussion that cannot be addressed in detail here. ${ }^{28}$ Two facets are pertinent in this respect. Firstly, many of Wagner's theoretical writings place the concept of art-religion in an anti-Semitic context. In combination with the aforementioned blend of a "pure" Christianity and Nordic myth, they lend themselves easily to völkisch (art-)religious interpretations. Secondly, Wagner's operatic work itself does not make open mention of Jews, neither does his seminal essay, "Artwork of the Future." However, his antagonists, such as Alberich and Mime in The Ring, display characteristics that are typical of contemporary antiSemitic stereotypes and can be decoded as allusions to the negative influence of 'capitalist Jews' by an audience that shares these codes. ${ }^{29}$

With regards to the popularization of Wagnerian images of Nordic myth and the establishment of a neo-Germanic religion, the reception of Wagner is even more influential than his theoretical concept of art-religion proper. His art-religious ideas were taken up by his followers in the Bayreuther Kreis (Bayreuth Circle), under the leadership of Hans von Wolzogen between 1878 and 1938. Wolzogen, the Bayreuther Kreis, and its journal, Bayreuther Blätter, were responsible for an increasingly völkisch reading of Wagner, for a concentration on national heritage and the art of the past, which for them culminated in Wagner and did not include contemporary avant-gardes. Although the majority of the Bayreuther Kreis itself remained within a German-Christian

27 Richard Wagner, "Das Judentum in der Musik," in Sämtliche Schriften und Dichtungen, ed. Richard Wagner (Leipzig: Breitkopf und Härtel, 1911 [1850]); "Judaism in Music," in The Theatre. Richard Wagner's Prose Works (London: Keegan Paul, Trench, Trübner, 1894 [1850]).

28 The most prominent accusations against Wagner's anti-Semitism have been forwarded by Hartmut Zelinsky, Richard Wagner - ein deutsches Thema. Eine Dokumentation zur Wirkungsgeschichte Richard Wagners 1876-1976 (Frankfurt a.M.: Zweitausendeins, 1976); Rose, Revolutionary Antisemitism in Germany from Kant to Wagner; and Marc A. Weiner, Richard Wagner and the Anti-Semitic Imagination (Lincoln: University of Nebraska Press, 1995). For counterarguments see for example Dieter Borchmeyer, "Wagner und der Antisemitismus," in Richard-Wagner-Handbuch, ed. Ulrich Müller and Peter Wapnewski (Stuttgart: Kröner, 1986).

29 The contemporary reception of Wagner by many anti-Semites bears witness to this possibility. However, the opposite is true as well: a reception of Wagner's work ignoring these elements is possible and has certainly contributed to its continuing popularity. For a differentiated discussion of the latently anti-Semitic uses of language in Wagner's Ring see David Levin, Richard Wagner, Fritz Lang, and the Nibelungen. The Dramaturgy of Disavowal (Princeton, NJ: Princeton University Press, 1998), 30-95. 
religious paradigm, its influence on the German Faith and the Ariosophic movement was considerable, as will be discussed shortly. ${ }^{30}$

In addition to Wagner, there were two other theorists and popularizers of art-religion in Germany around 1900 whose legacies for the völkisch religious movement were instrumental, namely Friedrich Nietzsche (1844-1900) and Julius Langbehn (1851-1907). These two thinkers are vastly different from each other in sophistication and long-term international impact, but equally influential for German art-religion of the early 2oth century.

Friedrich Nietzsche's philosophy did not shape popular images of Nordic deities and myth as directly as Wagner's artistic work did. However, his antimonotheist, non-idealistic, tragic-heroic, aristocratic view of humanity contributed to alternative-religious, Neopagan, and Conservative Revolutionary worldviews to a degree which cannot be understated, and which was not limited to Germany. It is impossible here to do justice to the complex and changing attitudes toward the aesthetic in Nietzsche's philosophy and its extensive and diverse reception. ${ }^{31}$ Many Nietzscheans plainly ignored the fierce antagonisms that drove his work and understood his philosophy of 'life' as a holistic worldview, which based life as a whole on aesthetic values and thus excluded ethics not only from art, but from politics as well.

The immense popularity of nationalist readings of Nietzschean art-religion is confirmed indirectly by the reception of Julius Langbehn's culturally critical, nationalist manifesto, "Rembrandt als Erzieher" (Rembrandt as Educator, 1890). When the work first appeared anonymously, it stated only that it was written "by a German" ("von einem Deutschen"). ${ }^{32}$ Speculations ran wild that Nietzsche (whose "Schopenhauer als Erzieher" inspired the title) was behind this emphatic appeal for a spiritual renewal of the German nation. ${ }^{33}$ According to Langbehn, national rebirth was to be facilitated with the help of the German aesthetic heritage, by artists, as the "leading spirits," in search of a truly "national style,"34

30 For a discussion of the Bayreuther Kreis and the völkisch movement see Chatellier, "Wagnerismus in der Kaiserzeit," 585-595.

31 For an overview of the popular reception of Nietzsche in Germany see Aschheim, The Nietzsche Legacy in Germany 1890-1990. For a comprehensive discussion of Nietzsche's view of myth and his shifting concepts of art-religion see Lincoln, Theorizing Myth, 101120, and Williamson, The Longing for Myth in Germany, 234-284.

32 Julius Langbehn, Rembrandt als Erzieher. Von einem Deutschen (Leipzig: Hirschfeld, 1890).

33 Others imagined Paul de Lagarde or even Bismarck to be behind the anonymous author. Cf. Ingrid Oberndorfer, "Antisemitismus im 19. Jhdt. - August Julius Langbehn," David. Jüdische Kulturzeitschrift 57 (2003).

34 Peter Ulrich Hein, Die Brücke ins Geisterreich. Künstlerische Avantgarde zwischen Kulturkritik und Faschismus (Reinbek b. Hamburg: Rowohlt, 1992), 83f. 
the models and heroes of which were to be canonized artists such as Rembrandt, Dürer, and Goethe.

Both Nietzsche's and Langbehn's ideas permeated the life reform movement and its emphatic identification of 'natural' beauty and health, as well as the avant-garde aesthetic and elitist right-wing movements, and helped to forge links between them. ${ }^{35}$ Langbehn's enthusiastically received and widely read manifesto influenced a great number of art-reform associations in early 2othcentury Germany, among them the Deutscher Werkbund (German Association of Craftsmen, founded in 1907), ${ }^{36}$ the cultural reform journal Kunstwart (founded and edited by Ferdinand Avenarius), ${ }^{37}$ the art-education movement (Kunsterziehungsbewegung), ${ }^{38}$ and the Werdandi-Bund - named after one of the three norns (or fates) of Norse mythology, the norn of the present, or

35 According to Peter Ulrich Hein, the 'Germanization' and politicization of the Nietzschean version of art-religion should be understood in the context of a longing for a strong leader, a Führer, amongst German intellectuals in the early zoth century, and especially after ww I. This Führer was seen as a "potentiation of the Volk's characteristics." The German concept of Kulturnation saw the specific German character in the ability to unite essence and appearance in a higher form. Thus, this Führer came to resemble the ideal image of the artist. Ibid., 29. Such potentially totalitarian ideas were virulent in both expressionist circles as well as in the extreme right of the Weimar Republic, which tended to see the state, and politics itself, as an aesthetic institution. On the potential for totalitarianism of such art-religious ideas see Cornelia Klinger, Flucht Trost Revolte. Die Moderne und ihre ästhetischen Gegenwelten (Munich: Hanser, 1995), especially ch. 6. Hein, Die Brücke ins Geisterreich, 63 alerts to the fact that Armin Mohler, the apologetic theorist of the Conservative Revolution conceptualizes the movement as an aesthetic project himself: Mohler, Die konservative Revolution in Deutschland 1918-1932, 109. The disputed theories by George L. Mosse, The Crisis of German Ideology. Intellectual Origins of the Third Reich (New York: Grosset \& Dunlap, 1964); Roger Griffin, The Nature of Fascism; and Zev Sternhell, "Von der Gegenaufklärung zu Faschismus und Nazismus," who consider international fascism in the 2oth century as a predominantly cultural phenomenon are immensely helpful for an understanding of the right-wing art-religious ideas discussed in this chapter. For a summary of the controversies around these theories see Umland, Loh, and Griffin, Fascism Past and Present, West and East.

36 This umbrella organization sought to professionalize the numerous dilettante cultural associations in Germany and formed the cradle for the Bauhaus idea.

37 Cf. Hein, Die Brücke ins Geisterreich, 91-96; Marina Schuster, "Die Bildwelt der Völkischen," in Völkische Religion und Krisen der Moderne. Entwürfe 'arteigener' Glaubenssysteme seit der Jahrhundertwende, ed. Stefanie v. Schnurbein and Justus H. Ulbricht (Würzburg: Königshausen \& Neumann, 2001), 254f.

38 Hein, Die Brücke ins Geisterreich, 97-103. This movement promoted an organological model of art, saw the expression of mythic essences in a national art, and aimed at cultivating one's own myth and type as purely as possible. 
'becoming' - the umbrella organization for various strands of the völkisch art movement. ${ }^{39}$ Through figures like Wagner, Nietzsche, and Langbehn, as well as Felix Dahn, historian and author of the popular nationalist novel $A$ Struggle for Rome ("Ein Kampf um Rom") and other nationalist poetry, ${ }^{40}$ along with their followers, the connections between 'Germanic' mythology, German aesthetic and intellectual heritage, national rebirth, and the leading role of art and the artist became firmly established in this modern 'Germanic' art-religion.

\section{J.R.R. Tolkien and the Nordic Art-Religion of Middle-Earth}

These protagonists of a Nordic art-religious tradition were immensly important for the emerging Germanic Neopaganism in the German Faith Movement after 1900, and thus for later Asatru. However, another novelist, J.R.R. Tolkien

39 Cf. Rolf Parr, "Der 'Werdandi-Bund," in Handbuch zur 'Völkischen Bewegung' 187-1918, ed. Uwe Puschner, Walter Schmitz, and Justus H. Ulbricht (Munich etc.: K.G. Saur, 1996), 317. Inspired by Richard Wagner's idea of the total artwork, the Werdandi-Bund sought to unite religion, philosophy, and art in a new "German" folk-culture. It took an independent position between the Heimatschutz movement and its purely preservationist approach to German folk-culture, and the Werkbund, with its search for a national form of industrialized art and craft. The wide range of prominent members from all cultural spheres, including many activists of the Bayreuther Kreis, Paul Schultze-Naumburg of the Bund Heimatschutz, Kunstwart-editor Ferdinand Avenarius, Felix Dahn, Otto Höfler's father Alois Höfler, and even Theodor Heuss, the first liberal president of the Federal Republic of Germany after the war, testifies to the ideological breadth and influence of the WerdandiBund. Cf. also Chatellier, "Wagnerismus in der Kaiserzeit," 608.

40 Felix Dahn was an accomplished professor of jurisprudence and legal history when he published his four-volume novel, A Struggle for Rome (Felix Dahn, Ein Kampf um Rom, English translations by Lily Wolffsohn (A Struggle for Rome - The Ostrogoths and Belisarius, 1878) and Herb Parker (A Struggle for Rome, 2005) (Leipzig: Breitopf \& Sartel, 1876-1878)), which is set in Italy in the two decades after the death of the Gothic king Theoderic in $493 \mathrm{AD}$. In his fictional account, the fights between east and west Rome serve to convey a message of the degeneration and future restoration of the Gothic people and are given an implicit (national) religious or mythic content. Dahn makes a young warriorpoet into one of the last princely survivors of these struggles and lets him quite anachronistically be rescued by Vikings. Transferred to the North he and his young wife, an innocent child of nature, will assure the rebirth of this great nation in the future. Quite obviously, Felix Dahn ascribes a similarly national prophetic role to himself and assigns literature and poetry a prominent place in the national renewal which bears "Pagan" traits as well. Cf. Bernhard Viel, Utopie der Nation. Ursprünge des Nationalismus im Roman der Gründerzeit (Berlin: Matthes \& Seitz, 2009). 
(1892-1973), influenced the perception of European myth and folk belief after the 1960s in an unprecedented way and set the terms for the genre of fantasy literature. The fantastic world of his The Lord of the Rings trilogy has provided material for a whole industry of media, film, and games. ${ }^{41}$ In many aspects, Tolkien can be seen as a direct heir to the Anglo-Saxonist and Romantic constellation discussed above, with its characteristic merging of scholarship, myth, and aesthetic revival of myth. ${ }^{42}$ Philological theories of myth strongly influenced his literary work, and he supported the idea that myth can be reconstructed on the basis of a philological study of languages. His seeing languages as bearers of ancient mythological and cultural essences motivated his more activist, rather than antiquarian, relation to Old Norse material. ${ }^{43}$

41 Tolkien has received both immense praise as the "author of the [2oth] century" (Tom Shippey, J.R.R. Tolkien. Author of the Century (Boston/New York: Houghton Mifflin Company, 2002)), who lucidly anticipated green and alternative ideas, and equally outspoken scorn, as having written trivial, immature boys' stories with racist and misogynist undertones (see e.g. Guido Schwarz, Jungfrauen im Nachthemd - blonde Krieger aus dem Westen. Eine motivpsychologisch-kritische Analyse von J.R.R. Tolkiens Mythologie und Weltbild (Würzburg: Königshausen \& Neumann, 2003)), while his work has been largely ignored by academic literary criticism. The following discussion of Tolkien is based on Schnurbein, "Kontinuität durch Dichtung" and supplemented with arguments from Stefan Arvidsson's analysis, the most lucid interpretation of Tolkien's concept of myth currently available. Cf. Arvidsson, Draksjukan, 142-198.

Tolkien is another example of an accomplished academic-turned-mythmaker. He taught as a professor of Germanic philology at Oxford University, his main contribution to the field being a still-relevant essay on Beowulf. (Cf. J.R.R. Tolkien, "Beowulf. The Monsters and the Critics," Proceedings of the British Academy 22 (1936), reprinted in The Monster and the Critics and Other Essays (London: George Allen \& Unwin, 1983)). At the same time, he was a member of a circle of intellectual male friends, 'the Inklings.' They discussed and brought to life the mythical worlds they studied by identifying with figures from Old Norse or Old English literature. For a still authoritative and detailed biography of Tolkien see Humphrey Carpenter, J.R.R. Tolkien: A Biography (London: George Allen \& Unwin, 1977), for the Inklings see also Ronald Hutton, Witches, Druids and King Arthur (London/ New York: Hambledon and London, 2003), 215-238. Shippey, J.R.R. Tolkien. Author of the Century (XIV-XVI) compares Tolkien's academic and literary activities with those of Jacob and Wilhelm Grimm, particularly their literary and linguistic reconstructions of Germanic grammar, law, mythology, and fairy tales; with those of Elias Lönnrot who reconstructed the Finnish "national epos," the Kalevala, from disparate sources; and of Nikolai Frederik Severin Grundtvig, and his project of the reconstruction of a national Danish identity. See also T.A. Shippey, "Goths and Huns. The Rediscovery of the Northern Cultures in the Nineteenth Century," in The Medieval Legacy. A Symposium, ed. Andreas Haarder, et al. (Odense: Odense University Press, 1982), 64 f.

See Arvidsson, Draksjukan, 150. 
Tolkien deplored the lack of an original English mythology, which he sought to compensate for in his literary work. ${ }^{44}$ The choice of an aesthetic genre in this process of reconstruction points to an aesthetic attitude toward a critique of contemporary society, and the potential for its healing through ancient myth - not unlike that of Richard Wagner. Tolkien engaged extensively with Wagner's Ring of the Nibelung, although he claimed to detest him and rejected any such influence. ${ }^{45}$

A Herderian worldview, and its central assumption of a unity of landscape, language, and nation, resonates in the descriptions of the relations between the many creatures, peoples, and 'races' of Middle-earth in The Lord of the Rings. For Herder as for Tolkien, myth is fundamental for the formation of a people. It reflects a people's attachment to its landscape and history, transmiting ancestral traditions and forming its customs and morals. Neither Herder nor Tolkien submitted to a reductive blood-and-soil ideology, ${ }^{46}$ rather, their works are marked by an unresolved tension between universalism and cultural relativism. For Tolkien, the struggle between good and evil is universal and unites all races. Through this alliance, these various races also become aware of their common ancestral roots. The ideal state after the victory, however, is different: here, each race or species lives peacefully on its own native soil, mostly separated from other races. Migration, cultural exchange, and interbreeding are rare, and not seen as desirable. The only exception is the marriage between elves and men in the future class of rulers of the new monarchic order. This has more to do with the arrival of a new age in which the race of men leads Middleearth after the departure of the elves. The new ruling class is thus legitimized as the bearer of ancient wisdom, religion, and art, which the elves stand for in Tolkien's work. Søren Staal Balslev has thus argued convincingly that paradigms of racial hygiene and concern over the degeneration of bloodlines

44 Cf. Bradley J. Birzer, J.R.R. Tolkien's Sanctifying Myth. Understanding Middle-Earth (Wilmington, DE: ISI Books, 2003), 41f; Patrick Curry, Defending Middle-Earth. Tolkien: Myth and Modernity (London: HarperCollins, 1998), 3of; Hutton, Witches, Druids and King Arthur, 227, claims that Tolkien started out by constructing such a mythology, which was in place by 1920, and that his further literary work builds upon it.

45 For a good overview of the parallels between Wagner's and Tolkien's "Rings" see Arvidsson, Draksjukan, $148 \mathrm{f}$. It is above all the main symbol - the ring as a sign of the misuse of power - that unites the two works. It also deserves attention that Tolkien, in contrast to Wagner, did not combine his cultural critique with anti-Semitic sentiments, although his work is not otherwise free from racist imagery.

46 Ibid., 151, draws attention to the fact that Tolkien's idealization of a seafaring imperialist patriotism has left traces in Lord of the Rings. 
pervade the book. ${ }^{47}$ The racial stereotyping found in The Lord of the Rings resembles that of Herder (and the general colonial imagination), with darkskinned, slant-eyed evil creatures residing in the arid, hot, southern regions and infertile eastern regions, whereas heroic peoples, like the riders of Rohan, are blond, blue-eyed, and reside in the North-West. ${ }^{48}$ In Tolkien's world, however, evil or degeneration is not caused by an unfortunate climate, but is the result of processes of degeneration caused by an untrammeled hunger for power. This process is accompanied by both the darkening of physical features and linguistic degeneration. ${ }^{49}$

But what about religion in Middle-earth? While Tolkien describes the languages, mentalities, and cultural peculiarities of his 'races' in great detail, neither their religious practices nor beliefs are mentioned directly. Himself a devout Catholic, Tolkien claimed to have refrained from putting "anything like 'religion' or cults or practices in the imaginary world," in order to let the work as a whole stand out as "fundamentally religious and Catholic," religion being "absorbed into the story and the symbolism." ${ }^{50}$ As a result, the literary work itself appears as a great myth, or, as we might say in the context of our argument, as an emphatic expression of art-religion. A closer look at The Lord of the Rings shows that Tolkien amalgamates Christian ${ }^{51}$ elements with the images and ethics of the medieval Northern European tradition he taught all his life, and which he, in accordance with the spirit of his era and academic practice,

47 Cf. Søren Staal Balslev, "Blodsaristokrati i Ringenes herre og Det mørke tårn," Kritik 202 (2011), 94-97.

48 This does not imply that such Nordic-heroic peoples are without flaw - quite the contrary: their blind heroism and atavistic concept of honor is set negatively against the hobbits Frodo's and Sam's unassuming, humble, and altruistic heroism.

49 Thus, the orks are elves converted to evil, trolls were ents, Gollum is originally a hobbit etc. The distorted speech of Gollum and the Orks are examples of such linguistic degeneration. The fear of a degeneration and impoverishment of speech through institutions of political power such as the church, the court and the legal system are also a concern of Herder, who hoped for a renewal of language and literature through the vital impulses of folk song and Nordic poetry. Arvidsson, Draksjukan, 163, alerts to the Zoroastrian implications of this philosophy: the enemy creates evil through the perversion of the good.

5o J.R.R. Tolkien, quoted in: ibid., 237.

$5^{1}$ Some of the most prominent examples are Gandalf's resurrection, the ethics of compassion and humility, Frodo's ordeal which leads to the redemption of the world, and not least, the reinstatement of an idealized king in the spirit of an equally idealized Christian medieval sacral kingdom. For a comprehensive discussion of Tolkien's work's Christian message see Birzer, J.R.R. Tolkien's Sanctifying Myth. 
considered originally pre-Christian. ${ }^{52}$ This synthesis mirrors his conviction that Paganism needs to be sanctified by Christianity, but also that the Christianity of the present is in need of the values which, in Tolkien's eyes, characterize Nordic Paganism, in particular courage, strength, and will.53 A quote from Tolkien's essay on Beowulf shows that he assigned this heroic, courageous attitude characteristic of the "Northern mythological imagination" a continued strength and vitality in the present:

So potent is it [the Northern mythological imagination], that while the older southern imagination has faded forever into literary ornament, the northern has power, as it were, to revive its spirit even in our times. It can work, even as it did work with the goðlauss Viking, without gods: martial heroism as its own end. ${ }^{54}$

The quote is from 1936, and betrays a similar fascination with contemporary 'Germanic' revivals as C.G. Jung's "Wotan" essay, which assigns a very similar archetypal force to the Nordic gods. We could thus argue that the "Nordic Christianity' which Birzer correctly identifies as Tolkien's program, and which originates in Anglo-Saxonism, shows certain parallels to ideas of German(ic) Christianity propagated in early 2oth century Germany. ${ }^{55}$

The antagonists are similar in both Tolkien and the Germanic religious revival in Germany: contemporary decadence, untrammeled materialism and industrialism, represented by the utterly destructive nature found in Tolkien's gloomy descriptions of the land of Mordor. ${ }^{56}$ Positive and functional worlds in

$5^{2}$ One example is the imagery of the wanderer Gandalf as an Odin-figure. His name is taken from the Edda, as are the dwarves' names. The depiction of heroes resembles narrative patterns from the Icelandic sagas.

53 See Birzer, J.R.R. Tolkien's Sanctifying Myth, xxıII.

54 Quoted in Arvidsson, Draksjukan, 150. See Tolkien, The Monster and the Critics and Other Essays, 159 .

55 Cf. Arvidsson, Draksjukan, 159f. This is not an argument against Tolkien's fundamental and passionate opposition to National Socialism, which he thought had perverted the original Nordic values still very much alive in the English tradition. There is, however, a fundamental difference between the self-redemptive worldviews of Germanic Faith and German Christianity and Tolkien's ethics: for him, not the heroic deeds of an individual, but rather collaboration and compassion, are the character traits necessary to bring about redemption.

$5^{6}$ Again, we should note that in the case of Tolkien, and opposed to the often rabid antiSemitism of the Germanic revival in Germany, Jews are not made the culprits. At the most, a trace of a Christian anti-Jewish topos could be identified in the depiction of the 
The Lord of the Rings are characterized as being in tune with the natural world and nature itself, and plants and trees in particular are depicted as animated. This has motivated Patrick Curry, another defender of Tolkien, to describe the religious ideas at the base of The Lord of the Rings as a kind of nature religion modified by Christianity. He identifies animist and polytheistic elements in Tolkien's conception of myth, and emphasizes that conception's proximity to contemporary forms of nature-religiosity in Neopagan groups. ${ }^{57}$ The enthusiastic reception of Tolkien in different green spiritual movements (to which Curry himself belongs $)^{58}$ confirms this analysis, and the proximity between Tolkien's Herderian worldview and bio-regionalism, "'green' or 'brown' decentralism, and small-scale conservatism"59 cannot be dismissed. ${ }^{60}$ Neither can Niels Werber's claim that the worldview in The Lord of the Rings mirrors German pre-war geopolitical ideology. ${ }^{61}$ Rather, Tolkien appears to be a herald for a Nordic art-religion. In his essay "On Fairy Stories" (1947), ${ }^{62}$ Tolkien assigns fairy tales the capacity to open "a door on Other Time," which resembles Mircea Eliade's "jargonizing speech about in illo tempore,"63 talking about story-telling as a way for fallen man to return 'home,' to find a way to Eden. ${ }^{64}$ Through his literary work, Tolkien fashioned himself as a poetic genius capable of creating myth and thus conveying a religious message. ${ }^{65}$

dwarves (who are portrayed as 'Jewish' in a mostly favorable way). The dwarves awaken the creature Balrog who is to kill Gandalf later. This passage evokes the mythic guilt of killing a savior figure.

Curry, Defending Middle-Earth, 28f, 108-111, $122 \mathrm{f}$.

58 See for example his Ecological Ethics. An Introduction (Cambridge: Polity Press, 2006).

59 Arvidsson, Draksjukan, 164.

6o See ibid., 164. German Asatru bio-regionalist Thorsten Kramps referred to Tolkien as one important source of inspiration as well. See Chapter 6.

61 Niels Werber, "Geo- and Biopolitics of Middle-Earth. A German Reading of Tolkien's The Lord of the Rings," New Literary History 36, no. 2 (2005), 230, investigates the following dimensions of geopolitical discourse in The Lord of the Rings: "the construction of the other as an absolute foe in total warfare (section 2), the function in this construction of biopolitics (3), the belief that every nation takes part in a "clash" of ethnically shaped "greater regions" (4), that a politicized nature itself is mobilizing in a global and total war to end all wars (5), and that a secure international order could be expected only from a strict separation of nations (6)."

62 Re-published in J.R.R. Tolkien, The Tolkien Reader, 2. ed. (New York: Del Rey, 1986).

63 Arvidsson, Draksjukan, 173.

64 Ibid., 154 .

65 Ibid., 172. At the same time, there is an ambivalence in Tolkien's conception of free artistic creation, a never-quite resolved uncertainty as to whether it is a breach of God's plan or its realization. See ibid., 175 . 


\section{Religious and Ideological Art in the German Faith Movement}

Long before Tolkien-mania set in during the first decade of the 200os, converting Tolkienian worlds into popular games and religious practice, and any conceivable post modern hybrid of the two, leading figures of the German Faith Movement forged their own versions of the Nordic art-religious tradition. Quite a few of them were artists themselves. They considered art to be a religious medium and the artist to be a prophetic figure, quite literally assigning the poet a "sacred, almost priestly calling." 66 Furthermore, they conceptualized the "national, great, modern" drama as a religious means of counteracting the "bloody victories of Roman ecclesiasticism" 67 and a way to combine "art and devotion." 68 Before becoming the prophet of the Germanic occultist revival of Ariosophy, Guido von List (see Figure 9.1) had won some notoriety as the author of historical novels, short stories, dramas, and sacral plays teeming with equally sentimental and bloody imaginations of national rebirth through sacrifice and self-sacrifice. ${ }^{69}$ Remaining an ardent supporter of Wagner, List continued to style himself as a genius and prophet in Wagnerian fashion. More relevant still was Ernst Wachler (1871-1945), one of the first promoters of a German Faith and a leading figure in Ludwig Fahrenkrog's Germanische Glaubensgemeinschaft. To the broader public he was known as an influential literary critic, author, promoter of theater reform, and initiator of the German open-air theatre movement. ${ }^{70}$ In his 1897 pamphlet, "Läuterung deutscher Dichtkunst im Volksgeiste" ("Purification of German poetry in the spirit of the

66 Ernst Wachler, Läuterung deutscher Dichtkunst im Volksgeiste. Eine Streitschrift (BerlinCharlottenburg: Richard Heinrich, 1897), 16: "heiligen, fast priesterlichen Beruf."

67 Ibid., 20: "nationale, große, moderne" - "blutigen Siege des römischen Kirchentums."

68 Die Freilichtbühne. Betrachtungen über das Problem des Volkstheaters unter freiem Himmel (Leipzig: Fritz Eckhardt, 1909), 11: "Kunst und Andacht."

69 The only academic author who has addressed List's literary work in detail is Inge Kunz, "Herrenmenschentum, Neugermanen und Okkultismus," 14-90, in her unpublished dissertation.

70 The following is developed more fully in Schnurbein, "Religiöse Ikonographie - religiöse Mission. Das völkische Weihespiel um 1910," as well as in "Gjenbruken av edda-diktningen i 'völkisch-religiöses Weihespiel' rundt århundreskiftet i Tyskland.” For the broader background of Wachler's literary program and his theater projects see Puschner, "Deutsche Reformbühne und völkische Kultstätte," and Justus H. Ulbricht, "Die Geburt der Deutschen aus dem Geist der Tragödie. Weimar als Ort und Ausganspunkt nationalpädagogischer Theaterprojekte," in Wege nach Weimar. Auf der Suche nach der Einheit von Kunst und Politik, ed. Hans Wilderotter and Michael Dorrmann (Berlin: Jovis, 1999). 


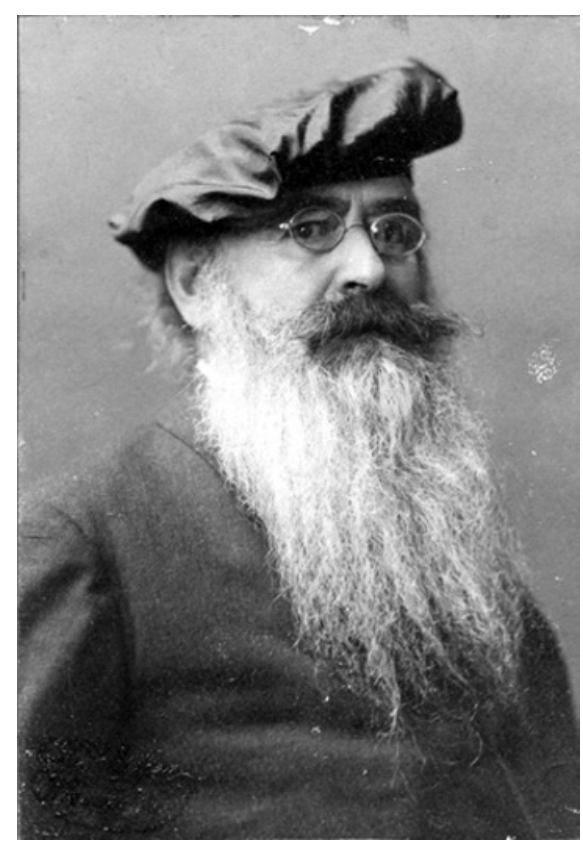

FIGURE 9.1

Portrait photograph of Guido von List (probably 1909/10) PUBLISHED WITH PERMISSION FROM THE GERMAN FEDERAL ARCHIVES (BUNDESARCHIV). BARCH, BILD 1832007-0705-500/CONRAD H. SCHIFFER

Volk"), ${ }^{71}$ he criticized the lack of a patriotic poetry for the new German Empire. ${ }^{72}$ He rejected the "elitism" of the classicist tradition as well as the "decadence" of naturalism, while promoting a regional poetry based in folk customs and literature. The dramatic genre for him constituted the only living, public, literary genre which truly existed in and for the $V_{0 l k}{ }^{73}$ as long as it succeeded in leaving behind the urban "theatre of luxury" and was made accessible to all classes in open-air theaters or in great halls. Another key condition was that it be based on traditional material such as myths and (fairy) tales, patriotic history, and folk custom ${ }^{74}$ originating in a "homogeneous," "cohesive" culture. ${ }^{75}$ The new theater

71 Wachler, Läuterung deutscher Dichtkunst im Volksgeiste.

72 Here, Wachler adopted the central position of the völkisch literary movement and its most prominent promoter Adolf Bartels (1862-1945). On Bartels cf. Thomas Rösner, "Adolf Bartels," in Handbuch zur 'Völkischen Bewegung' 1871-1918, ed. Uwe Puschner, Walter Schmitz, and Justus H. Ulbricht (Munich etc.: K.G. Saur, 1996).

73 Wachler, Läuterung deutscher Dichtkunst im Volksgeiste, 51.

74 Ibid., 42.

75 Ibid., 163: "einheitlichen" - "in sich geschlossenen." With this program, Wachler posits himself explicitly within the tradition of the 19th century German national political festival play (Festspiel). See, for example, Uwe-K. Ketelsen, "Das völkisch-heroische Drama," in Handbuch des deutschen Dramas, ed. Walter Hinck (Düsseldorf: Bagel, 1980); Bruno 
was to serve as the "solemn shrine of the whole people,"76 thus recreating the "religious, national, and popular fundament of the theatre" ${ }^{77}$ modeled on Greek tragedy. ${ }^{78}$

In order to realize his lofty ambitions, Wachler founded the Harzer Bergtheater in 1903, a 25-by-20-meter open-air stage, with seating for 1200 people, on a forest clearing in the Harz mountains. This location was chosen with a specifically religious purpose in mind, as the Harz was considered a preChristian site of worship..$^{79}$ Not only was the stage to become an altar, but the location of the theater itself was also turned into a place of worship, in synchronicity with the powers of nature and landscape. The Harzer Bergtheater was used for the activities of German Faith organizations such as the Deutschreligiöse Gemeinschaft and Germanische Glaubensgemeinschaft. At their gatherings, myth-inspired plays by Wachler and the organizations' founder, Ludwig Fahrenkrog, were performed as well. ${ }^{80}$ Thematically, the dramas often

Fischli, Die Deutschen-Dämmerung. Zur Genealogie des völkisch-faschistischen Dramas und Theaters (1897-1933) (Bonn: Bouvier, 1976); Georg Kreis, "Das Festspiel - ein antimodernes Produkt der Moderne," in Das Festspiel. Formen, Funktionen, Perspektiven, ed. Bernd Engler and Georg Kreis (Willisau: Theaterkultur-Verlag, 1988); Klaus Sauer and German Werth, Lorbeer und Palme. Patriotismus in deutschen Festspielen (Munich: dtv, 1971). Not surprisingly, Wachler praises Wagner as the "last great master" (letzte große Meister" Wachler, Die Freilichtbühne, 16), with one important reservation: He explicitly rejects the late Wagner's Christian ideas as well as the primacy of song, which he considered a "bastard," while praising the "purity" of the spoken word. (Läuterung deutscher Dichtkunst im Volksgeiste, 110).

76 Die Freilichtbühne, 13: "festliche Heiligtum des ganzen Volkes."

77 Ibid., 20: "religiöse, nationale und volkstümliche Grundlage des Theaters."

${ }_{78}$ With this, he placed his program in the German tradition of the quasi-religious celebration of Greek tragedy spanning from Romanticism to Nietzsche. Cf. Manfred Frank, "Vom 'Bühnenweihefestspiel' zum 'Thingspiel.' Zur Wirkungsgeschichte der 'Neuen Mythologie' bei Nietzsche, Wagner und Johst," in Das Fest, ed. Walter Haug and Rainer Warning (Munich: Wilhelm Fink Verlag, 1989), 611.

79 In another programmatic appeal, Wachler recommended to look for "old national sites of worship" for the new stages. Ernst Wachler, Sommerspiele auf vaterländischer Grundlage (Berlin: Vaterländischer Schriftenverband, 1910), 17.

8o Fahrenkrog's plays, Baldur and Wölund, served this purpose. Fahrenkrog, Baldur; Wölund. Cf. Puschner, "Deutsche Reformbühne und völkische Kultstätte," 780. See also the recent discussion of the uses of Eddic material in völkisch theater by Sven Neufert, "'Aus dunklen Tiefen empor zu lichten Höhen.' Die Edda-Rezeption in der völkischen Theater- und Festkultur," in Eddische Götter und Helden. Milieus und Medien ihrer Rezeption. Eddic Gods and Heroes. The Milieux and Media of Their Reception, ed. Katja Schulz (Heidelberg: Winter, 2011). 
revolved around the topic of a new age: a turning point in history announcing a decline, to be followed by a new awakening of the national spirit (mirrored in the cycles of nature). They propagated a new religion of knowledge and deed, where the god-like hero poses as an artist and Übermensch in the spirit of Nietzsche $(-$ anism $) .{ }^{81}$

The performances of these religious dramas served a dual purpose and were directed at two audiences simultaneously. On the one hand, they ministered to what could be called a missionary goal, namely to entertain a broader public and win it over to the religious and ideological messages of German Faith. On the other hand, they were directed at members and sympathizers of German Faith groups, who were able to decode their messages and experience them as an immediate expression of their own religious convictions and thus as a religious ritual.

The same is true for the Gesinnungskunst (art of conviction and persuasion) of visual artists associated with the German Faith Movement of the era. Their work was aimed directly at religious experience, conveying völkisch religious messages and thus contributing to the creation of 'congregations' of like-minded followers. ${ }^{82}$ Ludwig Fahrenkrog, the Wagnerian and Bayreuther Kreis member Franz Stassen (1869-1949), Hermann Hendrich (1854-1931), and Hugo Höppener (alias Fidus, 1868-1948) produced paintings and easily reproducible graphic art. Their visual work was inspired by Jugendstil, and typically combined Wagnerian and Nietzschean themes with nature-religious impulses, merging them with symbols of national or racial purity, such as runes, swords, hammers, and the

81 This is most prominent in Fahrenkrog's figures of Baldur and Wölund, who unite features of the then-popular super-humans and Tatmenschen (Men of Deed) Lucifer and Prometheus. Friedrich Nietzsche used the figure of Prometheus, who steals the fire from the gods to give it to man, as a heroic (masculine) contrast figure to the "oriental" Eve of Genesis which is configured as a shameful (and feminine-coded) "fall from grace." See Lincoln, Theorizing Myth, 65 and Williamson, The Longing for Myth in Germany, 241. A comprehensive discussion of the reception of the figure of Lucifer around 1900 can be found in Ernst Osterkamp, Lucifer. Stationen eines Motivs (Berlin/ New York: de Gruyter, 1979). In contemporary theories of religion, both figures are associated with an alleged Germanic fire and sun cult, an idea put forward by Adalbert Kuhn on whose theories Nietzsche built his argument. Cf. Williamson, The Longing for Myth in Germany, 14f.

82 Marina Schuster, "Bildende Künstler als Religionsstifter. Das Beispiel der Maler Ludwig Fahrenkrog und Hugo Höppener genannt Fidus," in Kunst und Religion. Studien zur Kultursoziologie und Kulturgeschichte, ed. Richard Faber and Volkhard Krech (Würzburg: Königshausen \& Neumann, 1999), 276f. 
swastika. By far the most popular among the works of these graphic artists is Fidus' piece, Lichtgebet (Light Prayer, see Figure 9.2). It consists of the rear view of a muscular, young, androgynous, naked man on a rock in the mountains, reaching his arms and face toward the rising sun in a simultaneously contained and ecstatic gesture. ${ }^{83}$ It was not only the content of their work that turned these völkisch artists into true popularizers of Nordic art-religion, but also the distribution of their work through mass media. Fidus' and others' works were used as illustrations, vignettes, and ornaments in völkisch religious publications, such as the later editions of Wilhelm Schwaner's Germanenbibel, and Fidus himself traveled with slide presentations to promote his temple designs. ${ }^{84}$

Along with Fidus, Fahrenkrog and Hendrich also attempted to expand their religious artwork into architecture, and harbored plans for Germanic Faith temples. As Fahrenkrog's and Fidus' plans never materialized due to the lack of sufficient funds and supporters, the theater in Thale remained the only site where the German Faith art-religion found an actual location. This was also due to the work of Hermann Hendrich, co-founder of the Werdandi-Bund, an ardent Wagnerian and, as a member of the Deutschgläubige Gemeinschaft, supporter of a renewal of Germanic religion. ${ }^{85}$ In 1901, Hendrich realized his first architectural project in Thale. The Walpurgishalle, a blockhouse with 'old Germanic' elements inspired by stave churches and Viking architecture, was built by Bernhard Sehring according to Hendrich's design. (See Figure 9.3) In the hall, five monumental paintings of motifs from Goethe's Faust are exhibited. They merge Nordic imagery with allegedly Pagan witchcraft rituals, ${ }^{86}$ as well as the German classical tradition and the cult of the national genius, which Goethe had come to personify during the course of 19th-century German nationalism. Its location in nature, close to alleged ancient Pagan sites of

83 Höppener drew and painted the Light Prayer in several versions, and it was widely distributed through postcards and affordable prints, serving as an icon for the youth movement in particular, whose cult of youth, health, and nature it seemed to summarize in a compelling way. Cf. "Fidus - ein Gesinnungskünstler der völkischen Kulturbewegung," in Handbuch zur 'Völkischen Bewegung' 1871-1918, ed. Uwe Puschner, Walter Schmitz, and Justus H. Ulbricht (Munich etc.: K.G. Saur, 1996), 640; Y, Fidus, der Tempelkünstler.

84 Cf. Janos Frecot, Johann Friedrich Geist, and Diethart Kerbs, Fidus 1868-1948. Zur ästhetischen Praxis bürgerlicher Fluchtbewegungen (Munich: Rogner \& Bernhard, 1972).

85 Puschner, Die Völkische Bewegung im wilhelminischen Deutschland, $228 \mathrm{f}$.

86 In the folklore of the region, the Harz and the Brocken mountains were believed to be the location of the witches' Sabbath, celebrated on the night to May 1. Goethe used this idea in Faust. 


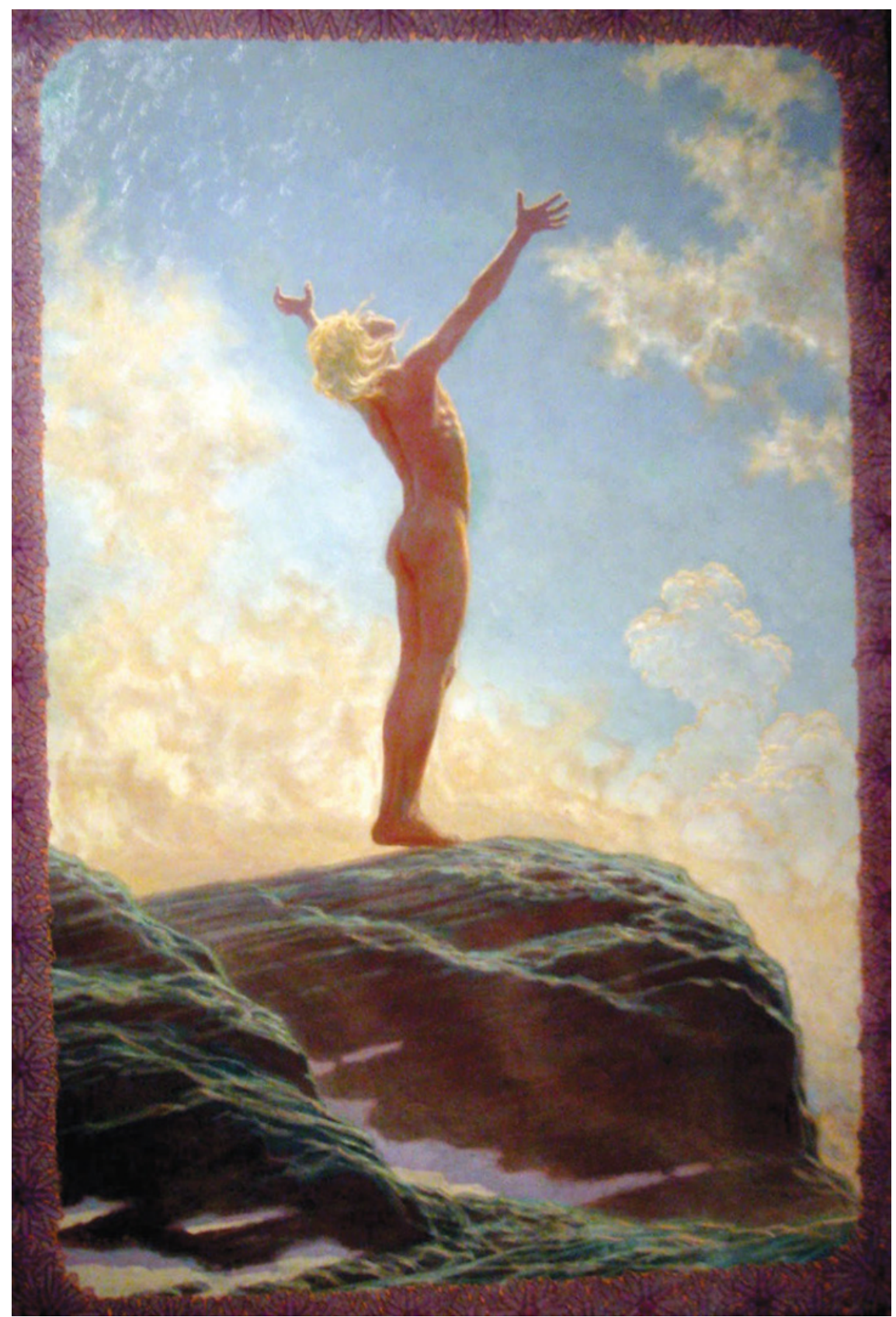

FIGURE 9.2 Fidus, Lichtgebet (1894/1924)

(C) VG BILD-KUNST, BONN 2014 


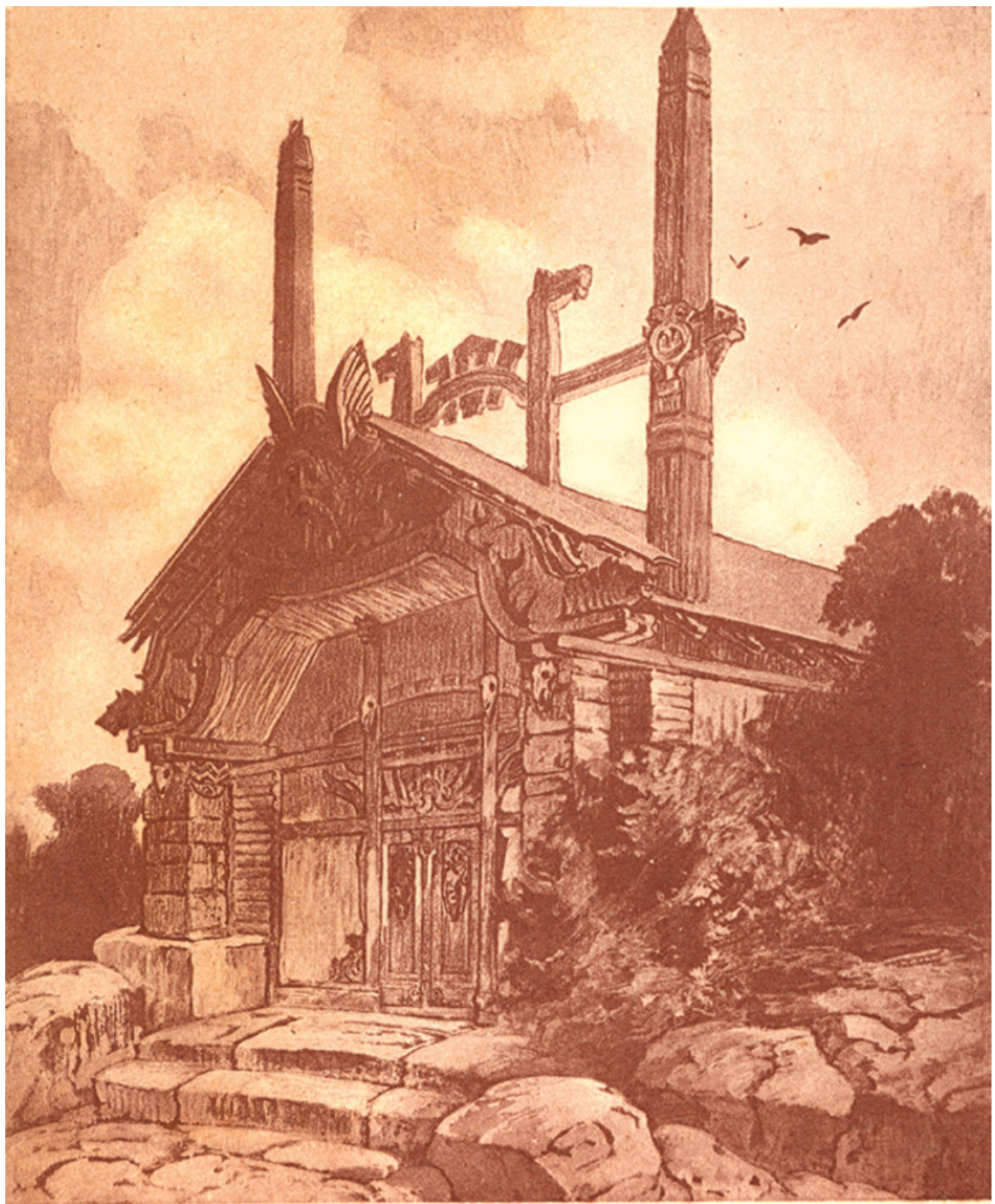

FIGURE 9.3 Painting by Hermann Hendrich, “Walpurgishalle," Hexentanzplatz, printed on postcard by Meisenbach, Riffarth \& Co., Berlin PUBLISHED WITH PERMISSION FROM GEORG JÄGER, WWW.GOETHEZEITPORTAL.DE.

worship, is characteristic of this new art-religion, being both regional and close to nature. It was thus mere coincidence that Wachler would then seize the opportunity to establish his völkisch religious theater project at this overdetermined location a few years later. ${ }^{87}$

87 Hendrich continued to realize similar projects celebrating a unity between a regional and mythic folk art in a second hall dedicated to German folk legends, the Sagenhalle in the 
Emphatic nationalist art-religious attitudes, which promoted the idea that the core of the German nation is to be found in its art, and which culminates in the idea that the Volk itself is the artwork and its leader the artist, permeate both the avant-garde and expressionism, völkisch (religious) and Conservative Revolutionary thought. ${ }^{88}$ Differences are found in the intellectual level and the grade of abstraction: völkisch art criticism and theory tend to turn to concrete symbols and images of the Germanic, and are characterized by a "tendency towards the trivial." ${ }^{\prime 9}$ This, however, does not necessarily mean that Conservative Revolutionary thinkers did not employ Nordic images, as the case of Ernst Jünger (1895-1998) shows. His images of the male hero, the figure of the warrior, and also that of the Waldgänger (forest walker) are taken directly from an intertextual engagement with Icelandic saga literature. His self-stylization as an author-prophet-seer, who alone is able to access myth and essential form, must be read within this context as well. ${ }^{90}$

\section{Heirs of Wagner and Tolkien: Asatru Novelists}

Modern Asatru recalls Romantic as well as völkisch art-religious traditions on a number of different levels. Asatruers tend to experience art as religion or religious inspiration, or they appeal emphatically to the spiritual quality of art itself and to the artist as a prophet, in stark contrast to adherents of Christianity, which is seen as a religion of legal codification rather than living inspiration, as is evidenced by this quote by Fritz Steinbock, of the German $V f g H$ :

In Paganism, poetry is a sacred art, the profession of the poet a religious task. Deities inspire the poets. In the Germanic tradition, it is none other than Allfather Wodan/Odin himself. Poetry thus stands in an immediate relation to prophecy. [...]

Riesengebirge in 1903. In 1913, on Richard Wagner's 10oth birthday, his Nibelungenhalle was opened in Königswinter at the Rhine river, where he exhibited paintings inspired by the Nibelungen cycle.

88 This theses is put forward by Hein, Die Brücke ins Geisterreich and "Völkische Kunstkritik," in Handbuch zur 'Völkischen Bewegung' 1871-1918, ed. Uwe Puschner, Walter Schmitz, and Justus H. Ulbricht (Munich etc.: K.G. Saur, 1996).

89 "Völkische Kunstkritik," 616.

9o This has been been shown by Niels Penke, Ernst Jünger und der Norden - Eine Inszenierungsgeschichte, Frankfurter Beiträge zur Germanistik (Heidelberg: Universitätsverlag Winter, 2012). 
Pagan poems have the character of mythic prophecies [...], of revelations - albeit not in the sense of immutable dogmas which are equally binding for everybody - these we search for in vain in Pagan poetry - but in the sense of a free and personal vision of divine reality, which in Paganism never declares itself in an authoritarian way nor requires blind faith. The gods do not proclaim who they are, but they show themselves and want to be experienced personally. [...]

Heathen tradition is based on this understanding of poetry as a sacred art, given by the gods, in which the gods speak themselves. Poetry is not fiction but truth - a truth that goes beyond mere actuality and lies in the nature of things themselves. It is the truth of the gods which speaks in poetry, because it is the language of the gods. The poet is the one who knows how to hear it and mediate it. ${ }^{91}$

Theodist Garman Lord goes a step further. He makes a strong ethnicist argument, claiming that it is the poet's task to see and point to the significance of the "organic processes" that form Germanic society and religion..$^{92}$ According to him, true poetry is made possible by the characteristics of the Indo-European language, the roots of which he imagines to lie in the Ice Age. ${ }^{93}$

$91 \quad$ Fritz Steinbock, "Die heilige Kunst - Dichtung und Wahrheit," VfgH e.V., http://www.vfgh .de/, last accessed November 04, 2011: "Die Dichtung ist im Heidentum eine heilige Kunst, der Beruf des Dichters eine religiöse Aufgabe. Gottheiten inspirieren die Dichter. In der germanischen Tradition ist es kein geringerer als Allvater Wodan/Odin selbst. Die Dichtkunst wird damit in unmittelbaren Zusammenhang mit dem Sehertum gestellt [...]. Heidnische Dichtungen [...] haben den Charakter von seherischen Kündungen, von Offenbarungen - allerdings nicht im Sinn unveränderlicher, für alle gleich verbindlicher Lehrsätze, die man in der heidnischen Dichtung vergeblich sucht, sondern im Sinn einer freien und persönlichen Schau der göttlichen Wirklichkeit, die sich im Heidentum niemals autoritär deklariert und blinden Glauben fordert. Die Götter verkünden nicht, wer sie sind, sondern zeigen sich und wollen persönlich erfahren werden. [...].

Auf diesem Verständnis der Dichtung als heilige, von den Göttern gegebene Kunst, in der letztlich die Götter selbst sprechen, beruht die heidnische Überlieferung. Dichtung ist nicht Fiktion, sondern Wahrheit - eine über die bloße Tatsächlichkeit hinausgehende Wahrheit, die im Wesen der Dinge selbst liegt. Es ist die Wahrheit der Götter, die in der Dichtung spricht, denn sie ist die Sprache der Götter. Der Dichter ist derjenige, der sie zu hören und weiterzugeben versteht."

92 Lord, The Way of the Heathen, 66.

93 Many Scandinavian Asatruers share the Romantic art-religious view of poetry as an important means of gaining access to the content and spirit of their religion. A long-term member of Danish Forn Siðr appreciates the fact that Asatru, from its beginnings, i.e. already in the medieval sources, is mediated in poetic form. Cf. for example Interview 
Völkisch religious artists such as Fahrenkrog, Fidus, Stassen, and Hendrich are promoted in the parts of Heathenism that align themselves with Conservative Revolutionary ideas and the New Right, the circles around the journal Tyr in particular. Here, illustrations by Fidus, Fahrenkrog, and other völkisch artists, such as Hans Thoma (1839-1924) and Franz von Stuck (18631928), are employed. ${ }^{94}$ Tyr published a comprehensive article about Ludwig Fahrenkrog by Markus Wolff, ${ }^{95}$ as well as reviews of a Hendrich biography ${ }^{96}$ and a CD honoring Hermann Hendrich. ${ }^{97}$ The Heidnisches Jahrbuch also contains a long article on Hendrich's work. ${ }^{98}$ The author, Thomas Lückewerth, is active in occultist circles ${ }^{99}$ and in an association called Nibelungenhort, whose purpose is to promote Hendrich's work today. ${ }^{100}$ The only recent monography available on Ludwig Fahrenkrog's life and work was written by Claus Wolfschlag ${ }^{101}$ and was released by the publishing house Zeitenwende (Turn of

I. Eggert Solberg Jonsson, “Ásatrú á Íslandi við upphaf 21. aldar," 117f, in his Master’s thesis on the Icelandic Heathen revival, claims that Romantic literature, plays, and art have great importance for current imaginations of the life and religion of the Heathen era.

94 Cf. Tyr I, 15, 26; Tyr II, 134; Tyr III, 122.

95 Wolff, "Ludwig Fahrenkrog and the Germanic Faith Community."

96 "Review of 'Hermann Hendrich: Leben und Werk' by Elke Rohling."

97 Tyr I, 271f.

98 Lückewerth, "Hermann Hendrich - Mythenmaler und Tempelkünstler."

99 He appears as an author in Shekinah, a journal for "shamanism, occultism, parapsychology and magic" edited by Holger Kliemannel (see also Chapter 6).

100 Cf. http://www.nibelungen-hort.de, last accessed September 02, 2014. Lückewerth, who prepares a monograph on Hendrich as well, praises Hendrich unequivocally as an artistleader, calling him a "tool" which "myth itself" has chosen and "through which it seeks incarnation" - a "willing tool of European transcendence," who "erected a temple for the Volk for its own old myths" and "leads us back to our own source." Lückewerth, "Hermann Hendrich - Mythenmaler und Tempelkünstler," 195: "errichtet er dem Volk einen Tempel für seine ureigenen Mythen;" and 229: "führt uns zurück zu unserer eigenen Quelle." Ibid., 229: "Der Mythos selbst hat Hendrich zum Werkzeug auserkoren und sucht durch ihn die Fleischwerdung. Die tiefe Sehnsucht nach dem Nordischen, den Sagas, den Märchen und Mythen, läßt Hendrich zum allzu willigen Werkzeug der europäischen Transzendenz werden." He follows the romanticizing idea that the Walpurgishalle is located at a Heathen site of worship and that Faust is a "Germanic" myth, and he praises the WerdandiBund as a promoter of "the healthy and life-affirming elements in art" as a "counterweight to the decadent and modern art-scene." Ibid., 196: "das Gesunde und Lebensbejahende in der Kunst zu stärken und ein Gegengewicht zur dekadenten und modernen Kunstszene zu liefern."

101 Claus Wolfschlag, Ludwig Fahrenkrog. Das goldene Tor. Ein deutscher Maler zwischen Jugendstil und Germanenglaube (Dresden: Verlag Zeitenwende, 2006). 
the Ages) in Dresden, which at least initially promoted New Right ideas and continues to collaborate closely with Arun Verlag. ${ }^{102}$

While the reception of völkisch art remains confined to a small circle within Heathenism, Richard Wagner and J.R.R. Tolkien constitute important sources for Asatruers in all countries. ${ }^{103}$ Although many Heathens today consider Wagner's "version of the religion [...] slightly warped," he is seen as a "deeply inspired man,"104 whose musical technique of leitmotifs are experienced by one author from the American The Troth as a "deeply spiritual element" reminiscent for him of the web of the wyrd. ${ }^{105}$ Tolkien's work is enthusiastically received by many Heathens. Pagan authors ${ }^{106}$ refer to him as part of exactly this neo-Romantic mythic tradition, and thus as an important contributor to the revival of Germanic faith. In this context, he is appreciated for his stance against the National Socialist appropriation of Germanic myth. ${ }^{107}$ This enthusiasm is part of the more general post-war atmosphere in which the constellation of a Romantic art-religious mythical revival and (national) history continued to thrive in popular literary genres, namely historical and fantasy novels. Popular books and films claiming to bring to life ancient rites and customs in the guise of either wholly imagined or fictional historical worlds are among the most regularly mentioned sources of inspiration for contemporary Asatruers. By now, the market for

102 Wolfschlag himself is involved with the German New Right, writing in the right-wing journal Junge Freiheit, and has published a book on anti-Hitler Conservative Revolutionaries with Arun Verlag, which contains a section about Fidus. Cf. Thomas Grumke and Bernd Wagner, Handbuch Rechtsradikalismus (Cologne: Leske \& Budrich, 2002), $45^{8}$. According to the owner, Zeitenwende has published exclusively esoteric books since 2003, among which Wolfschlag's publication on Fahrenkrog is obviously counted. Cf http:// www.netz-gegen-nazis.de/artikel/verlag-zeitenwende, last accessed September 02, 2104. Other publications include a book on Rune Qui Gong (http://www.verlag-zeitenwende .de/epages/64479676.sf/de_DE/?ObjectPath=/Shops/64479676/Products/63-8) and Julius Evola's Revolt against the modern world. (http://www.amazon.de/Cavalcare-tigreDen-Tiger-reiten/dp/3934291228/ref=sr_1_2?s=books\&ie=UTF8\&qid=1409663285\&sr=12\&keywords=Julius+Evola. Both links last accessed September 02, 2014.)

103 Scandinavian Heathens, however, tend to rely more on their own countries' Romantic traditions and numerous re-tellings of Norse mythology.

104 Gundarsson, Our Troth, vol. I, 97.

105 Ben Waggoner, "Wagners Ring. Übersetzung aus dem Englischen und Literaturanhang von Kurt Oertel," Herdfeuer. Die Zeitschrift des Eldaring e.V. 2, no. 4 (2004).

106 A member of German Nornirs Att claims to have been inspired by Tolkien in his religious search. Cf. Interview with six members of Nornirs Ætt.

107 Gundarsson, Our Troth, vol. I, 107. 
fantasy and historical literature with 'Germanic' or 'Nordic' themes has expanded to an extent that makes it almost impossible to keep an overview of the relevant works and authors. The same applies to the film industry. I shall therefore limit myself to a more detailed discussion of a few texts and authors that have had close interactions with the contemporary Asatru scene. These include books which are produced by Asatruers and have reached a certain level of public recognition, books which have been produced in collaboration with Asatruers, and books which are widely read in Asatru circles, and thus significantly shape Asatruers' perception of their religion. Four novelistic sub-genres stand out here: historical fantasy, alternate history, historical novels about national icons, and urban fantasy.

Ever since Marion Zimmer Bradley's immensely successful best-selling novel The Mists of Avalon ${ }^{108}$ appeared in 1983, these genres have served not only as escapist entertainment. They have also been received as models for religious orientation in present day life beyond or alongside Christianity. They are formulaic genres, whose easily accessible narrative structure seems apt for providing spiritual orientation. Historical fantasy in particular is a genre that lends itself to the purpose of envisioning what pre-Christian belief and practices might have looked like, and gives ample room for identification with the protagonists, whose psychological characteristics are portrayed in detail. They thus invite the modern reader to relate to their spiritual struggles and adversities. This explains the genre's popularity not only among Heathen readers, but also Asatru authors. Two of the most publicly visible a-racist North American Asatruers, Diana Paxson and Stephan Grundy/Kveldulf Gundarsson, make their living as authors of fantasy novels and have authored trilogies about the Nibelungen material. They make explicit references to the Romantic art-religious tradition by listing Wagner, Grimm, and Tolkien among their sources. ${ }^{109}$ They portray themselves as the heralds of Nordic art-religion, imbuing their own work with a religious message - a self-stylization mirrored in the role the poet or story is assigned in the novels themselves.

Paxson relates her fictional writing directly to her religious development when she says that she found her way into Paganism at the same time as she

\footnotetext{
108 Bradley, The Mists of Avalon.

109 Diana L. Paxson, The Wolf and the Raven (Wodan's Children, Book 1 ) (New York: William Morrow, 1993), 313f, lists Jacob Grimm as one of her main sources, and uses a quote from Richard Wagner's Siegfried libretto as a motto for the third volume of Wodan's Children, $\mathrm{cf}$. The Lord of the Horses (Wodan's Children, Book 3) (New York: William Morrow, 1996), XIV. Grundy, Rhinegold, v, dedicates his book to Wagner and Tolkien.
} 
began writing. ${ }^{110}$ Her trilogy, Wodan's Children, in which she re-counts the Nibelungen material mostly from the perspective of women, focusing particularly on their role in religion and magic, ${ }^{111}$ is her greatest success in Germany and in Asatru circles in both North America and Europe. The novel's setting provides the opportunity to depict two aspects of an imagined Pagan spiritual world - a fertility religion centered on the sacred marriage between sacred king and land (in the figure of the queen), and a shamanic magic religion. Bearers of the latter are Sigfrid, with his 'wolf magic,' and Brunahild, who is a member of the 'valkyries,' a Pagan order of 'wise women.' In the novels, Wodan is a god continually in search of wisdom, which he gains through accessing human experience. In this way, ritual and magic, as well as poetry, are depicted as means of gaining insight into the hidden connections of fate, which are not merely historical, but eternal. The novel ends with a prophecy about the return of the gods:

Wodan still walks the world, though men no longer recognize him, learning, experiencing, testing the new ways of thinking to which they turned when they abandoned their old gods. He is very curious, that one, and will follow the path to its end. When that time comes, perhaps he will seek a new way of knowing, and take up his conversation with Erda once more. [...] The ravens still fly, and to whom do they report, if not to the god? In every word that you speak and thought that you

110 Cf. V. Vale and John Sulak, Modern Pagans. An Investigation of Contemporary Pagan Practices (San Francisco, CA: Re/Search Publications, 2001), 23f. This happened in the circle around Marion Zimmer Bradley, her brother Paul Edwin Zimmer, and their adopted brother, whom Paxson married and with whom Paxson experimented around magical and Pagan rituals in the 1970s. At the time of writing, Bradley herself experimented with occultism and esoteric magic, and co-founded a Wiccan group centered on the Goddess, the Dark Moon Circle. Cf. ibid., 22. Paxson participated in Bradley's bestselling success The Mists of Avalon for which she provided information about Pagan women's rituals (cf. Bradley, The Mists of Avalon, Acknowledgements), and the sequels of which she coauthored and later authored individually. By now, the Avalon series contains the following titles: The Fall of Atlantis (1987), The Forest House (1993, with Diana L. Paxson), Lady of Avalon (1997, with Diana L. Paxson), Priestess of Avalon (2000, with Diana L. Paxson), Ancestors of Avalon (2004, written by Diana L. Paxson), Ravens of Avalon (2007, written by Diana L. Paxson), Sword of Avalon (2009, written by Diana L. Paxson).

111 Paxson, The Wolf and the Raven (Wodan's Children, Book 1); The Dragons of the Rhine (Wodan's Children, Book 2) (New York: William Morrow, 1995); The Lord of the Horses (Wodan's Children, Book 3 ). 
think, in the ecstasy of every new idea he is there, whether or not you know his name...112

The direct address to the reader makes it clear that this prophetic ending is written with the purpose of convincing readers that this story and its religious message are relevant for the present as well. Considering the fact that the rituals depicted in the novel are based on the author's own experience, ${ }^{113}$ it becomes clear that Paxson directs her writing at a two audiences simultaneously, in a manner similar to that of Ernst Wachler's sacral plays: a general audience that might be won over to Paganism, and an 'initiated' audience that will recognize their own beliefs and practices in the text, or perhaps draw inspiration for the design of their own religious practices from it.

A similar combination of references to a Romantic tradition of myth revival and art-religion based in personal religious experience can be found in the work of Stephan Grundy. Stephan Grundy's Rhinegold was first published in a German translation in 1992, ${ }^{114}$ became an immediate bestseller in Germany, and was equally popular in German Heathen circles. ${ }^{115}$ Grundy uses his own religious experience (which in turn is influenced by the academic knowledge gained through his simultaneous studies in German and English philology) in his descriptions of the ritual, magical, and religious plot of the novel. In accordance with Grundy's interest in runes and magic, Wodan appears as the god of the runes, which are understood as an expression of cosmic forces weaving together earth, gods, humans, and fate - a view which recalls the rune magical theories of Edred Thorsson. Thorsson advised Grundy to use the Nibelungen material for a novel and, according to Grundy, served as "a mentor of mine and a crucial influence on my writing and my interest in approaching Norse magic and religion from an academic viewpoint."116

\footnotetext{
112 The Lord of the Horses (Wodan's Children, Book 3), $366 f$.

113 Cf. Correspondence with Stephan Grundy (The Troth), who writes: "A number of the rituals that she describes were taken directly from rituals practiced by her divinatory group Hrafnar."

114 Several English and American publishers had turned down the manuscript. The German translation by the same translators who had worked on The Mists of Avalon, Manfred Ohl and Hans Sartorius, was published by Wolfgang Krüger Verlag, an established publisher of popular literature.

115 See for example Rabenclan's journal Heidenarbeit, 2 (1995), 37 as well as Correspondence with Kurt Oertel (Eldaring).

116 Correspondence with Stephan Grundy, 2014.
} 
The human part of the magic runic web upon which Rhinegold's world is based is cast in metaphors of blood and earth. It is Wodan's blood which courses through the Wälsungen's veins. It serves as the store for ancient genealogical and magical knowledge, and roots its members in the holy earth. ${ }^{117}$ The prophetic vision Grundy provides at the end of his novel is based on blood and genealogy as well. After Gudrun has sunk the last parts of the dragon's treasure in the Rhine, she hears Wodan's voice ringing "through her skull":

'Though the new ways may seem to bode the death of our kin, I have wrought so that our foes' work shall not last for ever, nor our voices be for ever stilled. Do not weep, but watch and learn.' [...] She could feel the rushing of her blood in the riverways of her body, the might running unseen through her, flowing unbroken from him who had named himself Mannaz to father the first of humankind. The same might whispered in every breath she drew, as she know it always had, though she had never marked nor thought of it till now; and she knew that no Christian dewsprinkling nor Latin prayers could still Wodan's gift in her children, or the children who would come of her folk, though the god's own kin forsook his memory. 118

Wodan then prophesizes that the stories just told will not be forgotten, and indeed "live through the long northern nights, even to the very doors of the White Christ's church."119 Grundy's art-religious prophecy is thus directly connected with the cosmic web of ancestral blood and runic power. ${ }^{120}$ The author implicitly ascribes such a prophetic function to himself, thus counting himself among those "who first in our time brought the gold forth from the dragon's mound and

117 For a more detailed discussion of these elements in Rhinegold see Schnurbein, "Kontinuität durch Dichtung."

118 Grundy, Rhinegold, 853 .

119 Ibid., 854.

120 In spite of such associations to a blood and ancestry, and some examples of racial stereotyping in the novel, Grundy is certainly not a supporter of racial theories in Asatru. In the sequel to Rhinegold, 1996's Attila's Treasure, the blood metaphors and racial stereotypes have all but vanished from the descriptions of magical practices. They are replaced by reflections on different systems of gender and sexuality and by the focus on protagonist Hagan's shamanic experiences, with which the author quite obviously identifies, and which are situated in a realm between genders and human and non-human worlds, making space for Hagan's bisexual leanings as well. 
the dark waters of the Rhine to awaken our memories of our northern forebears"121 - Richard Wagner and J.R.R. Tolkien, to whom he dedicates his book.

Alternate history, otherwise known as historiographic metafiction, is a popular genre that allows for creative imaginations of a different historical outcome due to the changing of crucial historical details. Harry Harrison and John Holm's 1990's trilogy, Hammer and Cross, explores the consequences of such a fictitious historical development. Instead of the church, a coalition of English insurgents and Pagan Vikings have gained power over Northwestern Europe in the years between $865 \mathrm{AD}$ and the reign of King Alfred (who is depicted as an honorable, tolerant Christian and remains an admirable figure in the book). The spread of the concept of the fulltrúi, or patron deity, in American Asatru (see Chapter 3 ), has been attributed to these novels. ${ }^{122}$ Referring to church history, Old Icelandic sources, and the legend of the Holy Grail, the novels center on the protagonist Shef, a former slave who rises to become 'the one king' of Norse Heathen prophecies. Shef defeats the Christian army and the cruel, fascistoid Knights of the Lance, is crucified, rescued, and then survives in hiding and finally withdraws from political power.

Co-author John Holm is a pseudonym for Tom Shippey, the eminent Tolkien scholar and linguist. The worldview advanced in the novels can be attributed to a modernized Tolkien-inspired view of Nordic mentality and ethics. The novel's perspective on history is Anglo-Saxonist, and its message firmly anticlerical, rejecting organized religion altogether as both unnecessary and as an impediment to natural inventiveness, resourcefulness, and vigor. The novel ascribes the latter features mainly to the peoples of the North-West. They are initially embodied in the religion of "Asgard's Way," in which the protagonist finds his own destiny. Reminiscent of Tolkien, the ideal is a secularized merging of non-dogmatic Christian values, such as compassion, with the inspired, heroic, yet pragmatic Paganism, accompanied by a skepticism towards corruptive political power. The third volume of the trilogy is set in the Mediterranean, and shows the contributions of all existing religions to the Enlightenment, which starts about 800 years earlier than in factual history. Despite its claim about the positive forces in all religions, the volume is infused with common stereotypes, particularly those of an overly refined, decadent, and cruel Islam,

\footnotetext{
121 Grundy, Rhinegold, v.

122 Cf. Harry Harrison and John Holm, The Hammer and the Cross [Der Hammer des Nordens (2001)] (New York: Tor Books, 1993); One King's Way [Der Pfad des Königs (2001)] (New York: Tor Books, 1995); King and Emperor [König und Imperator (2001)] (New York: Tor Books, 1996). Many discussions on www.asatrulore.org (last accessed September 02, 2014) give this information.
} 
which in the universe of the novel lacks any kind of creativity, and merely preserved the book-knowledge of antiquity the vigorous Northerners make productive use of. ${ }^{123}$ Transcendent religions appear as incapable of innovation, and serve as a negative backdrop for the inventive brilliance, democraticmindedness, and psychological maturity of Shef, under whose genial leadership all the world's progressive forces gather. Implicitly, it is Anglo-Saxon individualism that is assigned benevolent leadership over the rest of the world and its less independently thinking and acting inhabitants.

Not only alternate history sells in Asatru-circles ${ }^{124}$ and among the general public. As we have seen, popular historical fantasies have an abundant market, be it in the shape of re-enactment, experiential archaeology, role-play, or computer games. This trend is accompanied by an ever-increasing number of historical novels and films, ${ }^{125}$ among them those that re-tell national myths for contemporary audiences. An example which has been resonant in Heathen circles in England and Germany is Bernard Cornwell's book series on King Alfred, ${ }^{126}$ the 'founder' of united Anglo-Saxon England. Its success among Heathens is related to Cornwell's choice of narrator and figure of identification. The fictional character Uhtred, King Alfred's most important and successful warrior and commander, is born Christian but raised by Danes in the Pagan faith, to which he remains true all his life. This allows the author to present a skeptical view of the Christian religion, whose theological convictions remain

123 As we have seen in Chapter 5, such stereotypes origin in Enlightenment thought itself.

124 A Swedish example is the crime novel Odens öga (Odin's eye) by Håkan Strömberg, Odens øga (Stockholm: Ordfront, 2002), which takes place in a contemporary Sweden in which Christianisation and reformation have not been completely successful. Thus, religious conflict involving marginalized and discriminated Heathen groups, which have militant factions as well, dominate the political scene. The book was fairly well received by Asatruers for its inspiring descriptions of ritual and the overall imagination of how a Pagan tradition might function in the contemporary world. Cf. for example discussions in Samfundet Forn Sed's internet forum http://forum.samfundetfornsed.se/, last accessed September 15, 2014.

125 Films that are frequently mentioned by Asatruers include Conan the Barbarian (1982) and The Thirteenth Warrior (1999). Taking inspiration from Norse sources and scholarship, such films blend Wagnerian aesthetics with historical, mythic, fantasy, and horror elements, and create fantastic worlds that distribute images of 'Germanic' barbarians and heroes more widely.

126 Bernard Cornwell, The Last Kingdom (London: Harper Collins, 2004); The Pale Horseman (London: Harper Collins, 2005); The Lords of the North (London: Harper Collins, 2006); Sword Song (London: Harper Collins, 2007); The Burning Land (London: Harper Collins, 2009); Death of Kings (London: Harper Collins, 2011). 
as incomprehensible and foreign to Uhtred as they might be to the intended reader, the 'secularized' male youth of today. On the other hand, it portrays Uhtred's and the Danes' Paganism as a straightforward warrior religion, characterized by an ethics of valiant struggle and worldly pleasures, which remains grounded and avoids exaggerated heroism.

The books are quite obviously intended for an audience interested in the technicalities of medieval warfare and battle. They teem with detailed descriptions of weaponry and battle techniques. However, the underlying message of this re-imagination of the origin of the English nation seems to be that England has its roots not only in the activities and grand visions of a Christian king, as the chronicles and official historical records would have it. It is also based on a Pagan warrior spirit, which is rendered much more admirable and accessible to the reader than its Christian counterpart. Furthermore, the author ties Uhtred into his own line of ancestors and alludes to his own identification with this Paganism. He writes in the "Historical Note" to one of his books: "There was an Uhtred involved in those years, and he is my direct ancestor, but the tales I tell of him are pure invention. The family held Bebbanburg (now Bamburgh Castle in Northumberland) from the earliest years of the AngloSaxon invasion of Britain until the Norman Conquest."127

A German equivalent to this re-imagination of the origin of the English nation is Iris Kammerer's trilogy, which recounts the defeat of the Roman legions under Varus by Arminius ${ }^{128}$ - the historical event that has been considered foundational for German nationalism since the Germanic renaissance in humanism. The protagonist is a fictional Roman centurion, who for a period after the battle lives as a captive of a Germanic tribe, eventually eloping with and marrying the chieftain's daughter. The author succeeds in simultaneously portraying the Germanic "barbarians" and their struggle against Roman imperialism sympathetically and with understanding, and characterizing the 'national hero' Arminius as a cruel, deceptive traitor to his own people. Consequently, the clashes and mixes of cultures in the frontier area are depicted as formative for the later development of the region. Combined with the outspoken skepticism towards militarism and male heroism (the protagonist is an accomplished officer and fighter, but he is also depicted as suffering from severe war trauma) the trilogy's message is a far cry from the German national heroic myth of Hermann. The novels' success among German Asatruers is

\footnotetext{
127 Death of Kings, 333.

128 Iris Kammerer, Der Tribun (Munich: Heyne, 2004); Die Schwerter des Tiberius (Munich: Heyne, 2004); Wolf und Adler (Munich: Heyne, 2007). The books thus appeared in good time before the 2000-year anniversary of the battle in the Teutoburg forest in 2009.
} 
related to the fact that their author sought help from Eldaring members for the depiction of ritual and customs, and according to Kurt Oertel, contributed significantly to a more differentiated view of Arminius within Asatru. ${ }^{129}$

In Scandinavia, nearly each generation of authors and readers has had their favorite re-telling of Scandinavian mythology in the spirit of their respective era, some of which - in contrast to the aforementioned popular novels in the us and Germany - found their way into the canon of high literature. In Norway, Vera Henriksen's historical novels ${ }^{130}$ remain popular reading and have inspired Asatruers, as have Tor Åge Bringsværd's creative imaginations of the Norse deities' adventures and morals. ${ }^{131}$ In Denmark, the children's books on Erik Menneskesøn by Lars-Henrik Olsen and the immensely popular Valhalla cartoons, ${ }^{132}$ both of which continue to form younger Asatruers' worldviews, work with a similar concept: the insertion of human children into the mythological plots, like the looming decline of the world in Ragnarok. ${ }^{133}$ These Danish texts can be considered as belonging to another genre that has been important for the popularization of Norse mythology and served as inspiration for Asatru, namely, fantasy novels set in contemporary, often urban, contexts, in which deities make their appearance. Similar to the völkisch sacral plays at the beginning of the 2oth century, and to the historical novels that are often located in the era of the religious shift of Christianization, they make use of the idea of a shift in eras, the potential for the beginning of a new age in our times. Diana Paxson's second novel, Brisingamen, ${ }^{134}$ is an example of such an urban fantasy. It features a vision quest in which listening to a Wagnerian opera plays a key role. It ends in a wild, magical battle between humans who embody the Norse gods and their adversaries. Not only does this novel portray the lives of

129 Kammerer thanks Oertel, with whom she collaborated closely, working out the details of Germanic religious practice for the first volume for an "intensive academic exchange." Der Tribun, 576. She also consulted with Eldaring co-founder Alex Jahnke regarding military knowledge for her novel Varus, which appeared in 2009. Correspondence with Kurt Oertel (Eldaring).

130 Vera Henriksen, "Historiske romaner," (Oslo: Aschehoug, 1980).

131 Tor Åge Bringsværd, "Vår gamle gudelære," ed. Dagny Hald and Thorstein Rittun (Oslo: Gyldendal, 1985-1992).

132 Peter Madsen, Valhalla, 15 vols. (Copenhagen: Carlsen Comics, 1979-2009). The German translations are popular with German Asatruers as well.

133 One of the authors of Valhalla, Henning Kure, is connected with Danish Asatru and has authored a number of articles in Forn Siðr's journal Vølse. Cf. International AsatruSummer camp 2009, “We Proudly Present: The Programme!," IASC Herald, http://www .asatru-summercamp.eu/docs/IASC_Herald-June-o9.pdf, last accessed January 02, 2012, 2.

134 Diana L. Paxson, Brisingamen (New York: Berkley, 1984). 
some of the early members of the $A F A$, which was then active in Northern California, ${ }^{135}$ Paxson also casts her alter ego, Karen, as the bearer of a reawakened magical tradition harking back to the Viking age. A more widely known and complex example is American author Neil Gaiman's humorous novel, American Gods, ${ }^{136}$ published in 2001, in which the gods are alive as long as people believe in them. The novel imagines gods as traveling and migrating with their believers. Many different kinds of deities now reside in America leading marginalized lives, on the brink of disappearance. Wednesday - or Odin - is the leader of the coalition of old gods struggling for their survival and return. ${ }^{137}$ The idea that gods exist only as long as there are believers gives literature about them a religious function:Writing about gods implicitly becomes an act of keeping them alive.

The award-winning Norwegian novel, Cornelius Jakhelln's "Gudenes fall" ("The Fall of the Gods") $)^{138}$ takes up almost all of the themes, motives, and philosophies discussed in this chapter in a complex and often humorous way, giving them a postmodern twist. The novel is well liked by Norwegian Asatruers, ${ }^{139}$ although its innovative form makes it much less accessible than the traditional and often formulaic fiction mentioned earlier. Gudenes fall plays with contemporary Norwegian slang (in which the sections by Odin are written), different Norwegian dialects, as well as contemporary Danish (Loki's language), which are all rendered in phonetic transcription. The plot is convoluted. Since the Christianization of Iceland in the year 1000, the Norse gods have resided in a second Valhalla Valhall underground. Odin plans their return to the surface and the extinction of mankind for the coming millennium. This plan is compromised by two factors. The first is Odin's admiration for some men's (no women among them!) creative genius. The other factor is the expelled dwarf Regin's successful attempt to build a totalitarian system of 'bionts': Genetically modified and perfected chimeras who serve as loyal, cruel, uniform, fascistoid fighting machines, killing almost all humans and fighting the gods in the millennial battle. The third relevant group of players in the final battle are the gods' traditional enemies and trade partners,

135 Prudence Priest claims in an interview to have been "written up anonymously" together with Steven McNallen in this novel. Cf. SilverWitch, "Just 'Wiccatru' Folk."

136 Neil Gaiman, American Gods (New York: W. Morrow, 2001).

137 Cf. Fulvio Ferrari, "Gods of Dreams and Suburbia. Old Norse Deities in Neil Gaiman's Polymythical Universe," in Eddische Götter und Helden. Milieus und Medien ihrer Rezeption. Eddic Gods and Heroes. The Milieux and Media of Their Reception, ed. Katja Schulz (Heidelberg: Winter, 2011).

138 Cornelius Jakhelln, Gudenes fall (Oslo: Cappelen, 2007).

139 Cf. for example Interview $\mathrm{O}$. 
the giants, who are slightly ridiculous creatures known for their poor memory. They went underground a few centuries after the gods, and accompany them back up to the surface. Their leader erects one totalitarian, monotheistic religious system after the other, starting from Christianity, through "sintologi" (a parody of Scientology), and finally "maxism" (Stalinism), an atheism-turned-religion.

The political message of this wild dystopian fantasy is undermined by irony and ambiguities. Odin and his best friend, the dwarf Hornbore, share the cultural pessimist outlook of artists and thinkers like Wagner, Nietzsche, and Heidegger, as interpreted by the Conservative Revolution and the contemporary New Right. This becomes especially clear in their contempt for the uncontrolled breeding of the human masses and their simultaneous admiration for the genius of the few. The result is a political aestheticism, for which the German prophets of an art-religion stand. This depiction of a Nietzschean Übermensch is ironically disrupted by the fact that Odin appears as an unreliable narrator, a failing spouse and distant father; he is far from the perfect embodiment of ideal values, and rather human. However, the self-stylization of the narrator as a knowledgeable, divine philosopher and an unpredictable, divine jester mirrors the cultural pessimist outlook of other modernist and post-modernist writers. Some of these writers (Knut Hamsun, for example) operated in close political proximity to nationalist, anti-Semitic, Conservative Revolutionary or even National Socialist ideology..$^{140}$

In this context, the novel's debt to art-religious discourse is important. It is mainly tied to music, to which Odin shows a particular attachment, and which ranges from Richard Wagner to Norwegian composer Geirr Tveitt, a supporter of the Norwegian radical National Socialist (but anti-Hitler) Pagan group around Hans S. Jacobsen. ${ }^{141}$ Norwegian (black) metal plays an ambiguous rolehere as well. Like the book itself, this musical genre, and the subculture surrounding it, combines an apocalyptic aesthetic, a fascination with war and warrior ethics, a misanthropic and misogynistic attitude, and the rejection of modern capitalist society with an interest for an ancient mythic heritage and its revival. Jakhelln is also a musician, who mostly works within in the metal

140 For a discussion of Hamsun's reactionary modernism see for example Schnurbein, "Knut Hamsun's Narrative Fetishism."

141 Cf. Emberland, Religion og rase, 311-353; "Im Zeichen der Hagal-Rune," 519-522. Tveitt set to music old Norse materials and texts, as well as nature themes. The most consequent realization of such Norse Neopagan ideas can be found in his Baldrs Draumr, which Odin frequently listens to in the novel. 
genre. He plays in the bands Solefald and Sturmgeist, ${ }^{142}$ and characterizes his music, which combines Norse mythological motives with Goethe's poetry, as "grim Germanic thrash metal."143 Having flirted with Satanism and Odinism as a teenager in the mid 1990s, Jakhelln turned to German and Norse material. Jakhelln traces his project of aesthetic violence back to two experiences of discrimination: His being bullied in school, and some events from the Parisian suburb where he lived while studying philosophy and where a confrontation with what he saw as 'anti-white racism' motivated him to embrace anti-Islamist and racist ideologies. The experience of being threatened because of being middle-class, bookish, and white - in other words, because of a position in society which is commonly perceived as entitling one to privilege - led to his wanting "to find out what suited my own heritage. Play black metal with a Germanic edge. So it became poems by Goethe; a fascination with German military history; singing in German."144 His aesthetic is influenced by his search for a Northern, white, male identity rooted in myth, tradition, and heritage - a search that fails to question the assumption that German military history,

142 The names of the bands are taken from the context of a 'Germanic' art-religion as well. Solefald is the name of a painting by national-Romantic Norwegian artist Theodor Kittelsen, and Sturmgeist is inspired by Goethe's early ballads. Cf. Cornelius Jakhelln, Raseri. En hvitings forsøk på en selvbiosofi (Oslo: Cappelen Damm, 2011), 132.

143 Ibid., 227. The quote is taken from an article Jakhelln published in the Norwegian weekly, Morgenbladet, shortly after the bombing and killings in Oslo and the island of Utøya on July 22, 2011, and which is reprinted in his book Raseri (Rage) from the same year. It is a (self-)critical investigation into the ideology and emotions of the perpetrator Anders Behring Breivik, with whom the author discovers similarities. The difference, however, is, that Jakhelln feels he has found an outlet for his own rage in literature and music, a strategy he strongly recommends to counter the turn to manifest violence.

144 From an interview with Jakhelln in Håvard Rem, Innfødte skrik. Norsk svartmetall (Oslo: Schibsted, 2010), 243: "Jeg var rett og slett interessert i å finne ut hva som passet til min egen arv. Spille black metal med germansk edge. Da ble det for eksempel dikt av Goethe, en fascinasjon for tysk militærhistorie, å synge på tysk.” This type of personal experience, which individuals who are in a privileged situation in a system, but do not have the personal experience of being so are subject to, is structurally typical for the many crises of modernity, including the "crisis of masculinity" which Jakhelln performs in his work. Here, the crisis and its conquering through art or intellectual activity can be interpreted as a reinstitution of the allegedly threatened position. This logic is explored with regard to Scandinavian and German literature in Stefanie v. Schnurbein, Krisen der Männlichkeit. Schreiben und Geschlechterdiskurs in skandinavischen Romanen seit 1890 (Göttingen: Wallstein, 2001), and with regard to English literature and a colonial logic in Yekani Elahe Haschemi, The Privilege of Crisis. Narratives of Masculinities in Colonial and Postcolonial Literature, Photography and Film (Frankfurt/New York: Campus, 2011). 
Goethe's writing, and Norse myth belong to the same "heritage." With his turn from Satanism to Odinism, and later to a more philosophical and literary based interest in Germanic and Norse heritage, Jakhelln is a typical representative of the contemporary music scene of metal and neofolk, in which European, mainly 'Germanic' or 'Nordic' Pagan, themes play a prominent role. ${ }^{145}$

Jakhelln has acknowledged such political implications in his book, "Raseri" (Rage, 2011), an idiosyncratic collage of older essays and articles and more recent multi-faceted reflections on them. Here, he promotes a philosophical Heathenism that combines a Spinozean pantheistic reading of the Norse gods with neo-Darwinist theories of genetics, breeding, survival of the fittest, and the transfer of cultural 'memes,' taken from Richard Dawkins. ${ }^{146}$ At the same time, he continues with his project of self-stylization as an 'angry white man' and avant-garde artist - a stylization in which the "Viking memes" that have survived a "thousand years of Christianity" play an identity-forming role. ${ }^{147} \mathrm{In}$ this sense, he has turned himself into a prophet of a Nordic art-religion, who follows a philosophical and artistic Heathenism without being affiliated with any Asatru group. ${ }^{148}$

\section{Dark Heirs of Wagner and Tolkien: Metal and Neofolk}

Since the 196os, rock music has made use of counter-cultural imagery of the Satanic and occult. ${ }^{149}$ The origin of modern Satanism lies in Romanticism. Artistic genres that employ it can be understood as heirs to the 'dark side' of Romanticism and its art-religious impulse. The figure of Mephisto in Goethe's

145 Up until 2011, Jakhelln perceived his own project as a primarily artistic and religious one, denying any interest in politics. However, the aesthetic and religious, or rather, artreligious concepts he employs, always already have (meta-)political implications; for example, through the aesthetisation of totalitarian political ideologies. Cf. Sandra Lillebø, "Dr. Jakhelln og Mr. Hyde," Klassekampen, December 02, 2011.

146 Cf. Jakhelln, Raseri, 48-50.

147 Ibid., 5 o.

148 He did, however, have contact with the Icelandic Ásatrúarfélagið, and Jörmundur Ingi features on Solefald's CD Red for Fire - An Icelandic Odyssey from 2005 with a recitation from the Eddic poem, 'Lokasenna.'

149 A major inspiration came from Aleister Crowley and the anti-egalitarian, radically individualist and hedonist ethics of Anton LaVey, the founder of the Californian Church of Satan. Cf. Gardell, Gods of the Blood, 287f; Christian Dornbusch and Hans-Peter Killguss, Unheilige Allianzen. Black Metal zwischen Satanismus, Heidentum und Neonazismus (Hamburg/Münster: Unrast, 2005), 84f. 
Faust, the embodiment of a longing for freedom and power and its destructive potential, is a prominent source of inspiration, as are the literary characters of E.T.A. Hoffmann and Charles Baudelaire. Authors such as Lord Byron, Percy Bysshe Shelley, and William Blake "disembedded the Devil, Satan, Lucifer from the narrow constraints of Christianity and re-embedded the figure in an aesthetic and classical context," merging it with other mythical figures, such as Prometheus and Pan. ${ }^{150}$ Together with the Nietzschean influence, the literary roots of modern Satanism draw attention to the aesthetic character of this movement. Satanic, anti-Christian, anti-egalitarian, and mythological imagery played a significant role in the deliberately shocking and anti-bourgeois aesthetic of heavy metal bands of the 1970s as well. Around 1990, the Swedish Metal group Bathory replaced Satan with the equally anti-Christian imagery of Viking warriors and Heathen mythology in their 'Asatru trilogy,' Blood Fire Death (1988), Hammerheart (1990), and Twilight of the Gods (1991). The imagery, lyrics, and musical language of these albums contained tributes to the Nordic art-religious constellation. The cover of Blood Fire Death featured an 1872 Romantic painting of the Scandinavian version of the Wild Hunt, Oskorei, by Peter Nicolai Arbo (see Figure 9.4); Hammerheart mentions Richard Wagner in the credits; and Twilight of the Gods uses lyrical themes from Nietzsche, as well as veiled references to the ss. It thus "deliberate[ly] flirt[s] with the iconography of fascism and National Socialism." 151

Other Scandinavian bands, such as Unleashed, Riger, Menhir, Enslaved, Einherjer, Bifrost, and Helheim followed in this newly established tradition, and gained popularity as well as notoriety in the first part of the 199os. The Norwegian black metal scene became notorious due to Varg Vikernes', of Burzum, and others' involvement in church burnings and two murder cases in the early 1990s. ${ }^{152}$ Vikernes later turned to an explicit anti-Semitic, racist, Germanic Paganism and founded the Norwegian Heathen Front - an organization that added other national chapters throughout the years

150 Petersen, "Introduction: Embracing Satan," 11. These mythological figures also became central icons for alternative religious movements around 1900, including for the völkisch religious movement. Ludwig Fahrenkrog for example merged Promothean and Luciferian traits in his Wölund character (cf. Fahrenkrog, Wölund). For the enthusiasm around Pan cf. Aleida Assmann, "Pan, Paganismus und Jugendstil," in Antike Tradition und Neuere Philologien. Symposium zu Ehren des 75. Geburtstags von Rudolf Sühnel, ed. Hans-Joachim Zimmermann (Heidelberg: Winter, 1984).

151 Michael Moynihan and Didrik Søderlind, Lords of Chaos. The Bloody Rise of the Satanic Metal Underground, Revised and expanded ed. (Port Townsend, wA: Feral House, 2003), 21 (cf. also 18-21).

152 The events are documented in ibid. and Rem, Innfødte skrik. 


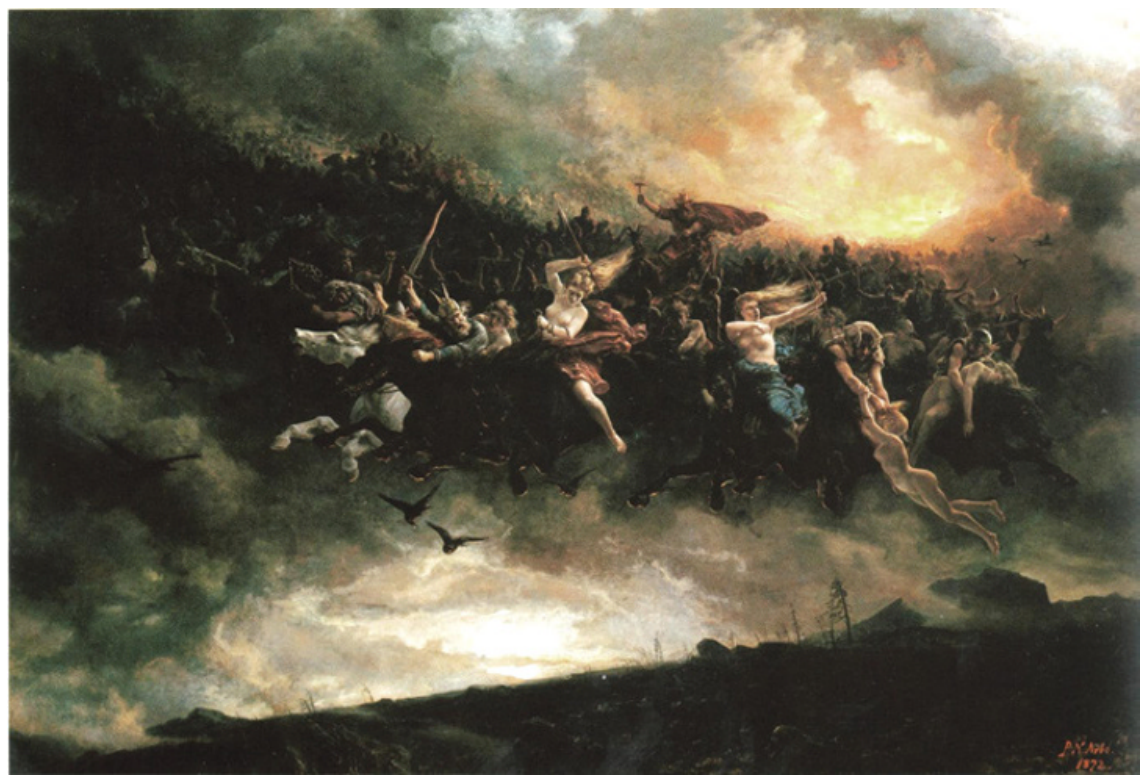

FIGURE 9.4 Peter Nikolai Arbo, Åsgårdsreien (1872)

PUBLISHED WITH PERMISSION FROM THE NATIONAL MUSEUM OF ART, ARCHITECTURE AND DESIGN IN NORWAY

under the umbrella organization Allgermanic Heathen Front $(A H F) .{ }^{153}$ Vikernes is a fairly marginal figure in Asatru today, and thus only of indirect importance for my investigations of the entanglements between current Asatru and music.

In order to understand the relationship between Asatru and the "EuroPagan"154 music scene, it is worth taking a closer look at the book from which much of the information on Heathen and Viking themes in black metal referred to here is gleaned: Lords of Chaos (first published in 1998), by Norwegian journalist Didrik Søderlind and Michael Moynihan. Moynihan has been a member of the Asatru Alliance, as well as of Stephen Flowers'/Edred Thorsson's Rune Gild, co-editor of Tyr and translator of Karl Maria Wiligut's work. (See Chapter 2) The authors themselves take a "mythic" approach to

153 Cf. Gardell, Gods of the Blood, 307.

154 The term stems from Stéphane François, "The Euro-Pagan Scene. Between Paganism and Radical Right," Journal for the Study of Radicalism 1, no. 2 (2007) and indicates that it is an aesthetic formation which is not held together by a particular musical style but by common references to 'Germanic' and 'Nordic' Pagan themes, or, to put it in the frame of this discussion, by the Nordic art-religious tradition. 
their subject. Beyond simply documenting the black metal scene, they want to identify its "metaphysical and spiritual underpinnings,"155 and they read it as the "return of an atavism." 156 Moynihan and Søderlind attribute the fact that this "atavism" or archetype breaks through in Scandinavia today to Northern Europe's late Christianization. ${ }^{157}$ Furthermore, they point to the important role which the barren Northern landscape and harsh climate play in black, Viking, and Pagan metal, 158 and claim that the "gods of the North seem particularly prone to stirring feelings which may unexpectedly resurge among the descendants of those who once worshipped them." 159 They thus use the "blood and soil' framework, which is constitutional for ethnicist Asatru, to explain the emergence of Heathen themes in music, the resurfacing of Asatru, and Vikernes' and others' crimes. ${ }^{160}$

As we have seen, such ideas of a mythic continuity were supported by scholars of the Romantic school and their followers around the turn of the century. They culminated in the 1920 s and 30 s in the theories of C.G. Jung and Otto Höfler, for example. Instead of talking about ancient mythic continuities, we can read Lords of Chaos as an appropriation of this type of holistic scholarship and its theories of völkisch unity and continuity, as discussed in Chapter 8. It is no coincidence that Höfler's theories, depicting the Wild Hunt in the Alpine area and its Nordic equivalent, Oskorei, as expressions of a ritual and social formation with roots in a deep Germanic past, inform both the music scene and Moynihan's and Søderlind's approach. The resurgence of the theme can already be found on Bathory's first album. Vikernes took it up in his fascination for, and identification with, the "werewolf warriors of the Oskorei"161 - a fascination that was soon shared by the Austrian musician Gerhard Petak, of the band Allerseelen, who at the time called himself Kadmon. His 1995 essay on the parallels between Oskorei and black metal quotes Otto Höfler frequently, and it became the primary avenue for the dissemination of Höfler's ideas in the

\footnotetext{
155 Moynihan and Søderlind, Lords of Chaos, 196.

${ }_{15} 6$ They borrow the term from Nietzsche and C.G. Jung, the latter of whom uses the concept in his essay 'Wotan.'

157 Moynihan and Søderlind, Lords of Chaos, 195.

158 Ibid., 203 .

159 Ibid., 204.

16o By referring to Stephen McNallen's observation of an 'organic' and synchronized revival of Asatru in the 1970s, they indirectly endorse Vikernes' own claims that the Norse gods are the archetypes of the Nordic race that break through, again quasi-naturally. Ibid., 204f.

161 Ibid., $196 f$.
} 
Alpine black metal scene. ${ }^{162}$ The wider distribution of Kadmon's essay can be attributed to Moynihan's and Søderlind's decision to add an English translation of it to the appendix of Lords of Chaos. Both Kadmon, as well as Moynihan/ Søderlind's book, thus contribute to a mythisation not only of black metal music, which Kadmon sees as a direct expression of Nordic cosmology, ${ }^{163}$ but of the church burnings as well, which they see as reflections of ancient European fire myths spun out of control. ${ }^{164}$

There is still another conclusion to be drawn from this. Moynihan makes frequent positive references to black metal musicians who seriously devote themselves to the study and revival of Norse myth. Kadmon does the same in his article when he praises musicians who, contrary to those using Nordic cosmology as "cosmetic make-up, decoration," take it "seriously, linking Ariosophic mythology together in their work with a mental attitude of self-respect and resistance, uniting them in a Nordic Nietzscheanism...Here Black Metal becomes a Pagan avant-garde, a Nordic 'occulture' reconciling both myth and modern world." 165

With the combination of Ariosophy and a Nietzschean ethic of self-reliance, Kadmon evokes the spiritual world of modern Asatru and links this version of Heathenism directly to the idea of an aesthetic avant-garde. Kadmon/Gerhard Petak and Moynihan themselves are younger members of a music scene

162 I here follow Florian Heesch's elaborate argument, cf. Florian Heesch, "Metal for Nordic Men. Amon Amarth's Representations of Vikings," in The Metal Void. First Gatherings, ed. Niall W.R. Scott and Imke v. Helden (Oxford: Inter-Disciplinary Press, 2010).

163 Kadmon in Moynihan and Søderlind, Lords of Chaos, 376.

164 Kadmon in ibid., 377. Moynihan/Søderlind even ascribe a prophetic quality to Vikernes' legal change of Kristian (meaning Christian in Norwegian) to Varg. They are reminiscent of allegedly obscure medieval and folkloristic uses of the term 'Varg' or 'Varg Veum' (old Norse for 'wolf in temple' as well as 'outlawed criminal'), which is associated with crimes like arson, grave robbery, treason, theft, and manslaughter, all crimes of which Vikernes was eventually accused or found guilty. However, there is no need to construct such esoteric connections about a sub-conscious prophetic application of this name. The term "Varg Veum" is quite well known in Norwegian and it was further popularized in the 1970s and 1980 os by Gunnar Staalesen, an author from Vikernes' hometown Bergen, whose Norwegian version of hard-boiled crime novels centred on a detective with this name. The first book in the series appeared in 1977. The eighth novel, Falne Engler (Fallen Angels), published in 1989, deals with Varg Veum's youth in the 1960s milieu of rock music. Cf. Gunnar Staalesen, Bukken til havresekken (Oslo: Gyldendal, 1977); Falne engler (Oslo: Gyldendal, 1989).

165 Kadmon in Moynihan and Søderlind, Lords of Chaos, 387. 
labelled neofolk, apocalyptic folk, Euro-Pagan music, or apoliteic music. ${ }^{166}$ They share its appropriation of a Pagan art-religious philosophy in the spirit of the German Conservative Revolution and European fascisms and fascist occultism. ${ }^{167}$

The collaboration of the Euro-Pagan music subculture in the USA and Great Britain with Asatru goes back as far as the 1970s. Neofolk's "ancestor,"168 Robert N. Taylor, of the band Changes, was one of the very few folk singers of the era to be involved with right-wing political organizations, including the paramilitary Minutemen, as well as with the Asatru Free Assembly and the Asatru Alliance. ${ }^{169}$ Neofolk proper emerged as part of the so-called "extreme culture" scene around punk/industrial/noise music of the 1970s. Part of this scene

166 Anton Shekhovtsov, "Apoliteic Music. Neo-Folk, Martial Industrial and 'Metapolitical Fascism," Patterns of Prejudice 43, no. 5 (2009).

167 Moynihan and Petak collaborated in several projects within this context, including the album Gotos = Kalanda (1995), based on twelve poems that Karl Maria Wiligut (alias Weisthor) wrote for Heinrich Himmler. Cf. Andreas Diesel and Dieter Gerten, Looking for Europe. Neofolk und Hintergründe (Zeltingen-Rachtig: Index Verlag, 2007), 236; Thomas Naumann and Patrick Schwarz, "Von der CD zur 'Lichtscheibe.' Das Kulturmagazin Sigill," in Ästhetische Mobilmachung. Dark Wave, Neofolk und Industrial im Spannungsfeld rechter Ideologien, ed. Andreas Speit (Hamburg/Münster: Unrast Verlag, 2002), 181. Wiligut's racial esotericism or National Socialist occultism has been a topic for both as writers as well. As mentioned earlier, Moynihan worked with Stephen Flowers on an English edition of Wiligut's texts, and Petak took up his theories in his journal Aorta (later Ahnstern). Cf. Diesel and Gerten, Looking for Europe, 243.

168 François, "The Euro-Pagan Scene," 37.

169 Having been a member of several occult and Satanic groups from the late 1960 os on, he and his wife Karen started to look for an alternative to these "elitist cults" as well as "witchcraft (Wicca) with its heavy post-hippie influences and its growing feminist and multi-cultural slant." (FluxEuropa, "Changes. Interview with Robert Taylor," Changes, http://www.nmia .com/ thermite/interviews/flux97.html, last accessed January 02, 2012) They founded the Northernway and, after a schism in the 1970s, The House of Wulfings and Wulfing Kindred, which became part of the Asatru Free Assembly, and after its demise, the Asatru Alliance. It was here that he met Michael Moynihan, whose label Storm first released Changes' songs recorded between 1969 and 1974 in 1996, and thus contributed to the renewed popularity of Taylor beyond Asatru circles. Taylor remains an active presence both within the music scene and American ethnicist Asatru up until today. Stephen McNallen's e-mail newsletter, AFA-Update, reports that "our long-time friend and musician" Taylor and Changes "entertained us with beautiful and stirring songs in the 'apocalyptic folk' genre" at the "Folkish Summer Hallowing, hosted by the Irminfolk in Pennsylvania." Stephen A. McNallen, "Folkish Summer Hallowing - an Asatru Affirmation!," Newsletter, AFA Update 150, August 24 (2011). 
centered around Asatruers and rune occultists such as Freya Aswynn ${ }^{170}$ and, a little later, Ian Read, the current leader of the initiatory, Ariosophically inspired Rune Gild in Britain. It took a turn from a provocative anarchism toward the revolutionary right during the 1980 . It started to embrace the idea of the artist as a Nietzschean Übermensch and turned to a more affirmative, although often ambiguous use of fascist, Satanist, and militant imagery. ${ }^{171}$ This change was accompanied by a gradual move away from synthetic sound and toward the use of more 'natural' acoustic instruments, and included medieval and Pagan themes that merged with fascist and occult, and increasingly also Ariosophic, elements. Aswynn herself appeared as a guest on several music productions with her runic chanting, ${ }^{172}$ as did other prominent Asatruers such as Heimgest, leader of the ethnicist British Odinic Rite, who performed a recitation of the runic alphabet on Sol Invictus' CD The Blade in $1997,{ }^{173}$ and whose article on runes was published in the booklet for the band's production Three Nine in 2000. ${ }^{174}$

Collaborations between music and religion extended to leaders of the Icelandic Ásatrúarfélagið as well. Gerhard Petak's Allerseelen used Sveinbjörn Beinteinsson's lyrics on his album Neuschwabenland in 2000. ${ }^{175}$ Nine years earlier, the Icelandic composer Hilmar Örn Hilmarsson, who was later to become allsherjargodi for the a-racist Ásatrúarfélagið, had moved in the extreme culture circles around performance artist Genesis P-Orridge's ironic sexual magic Temple Ov Psychick Youth. He collaborated with David Tibet from Current 93 on

170 It was in her London house that the members of what was to become the inner circle of early apocalyptic folk, the so-called "family" around Douglas Pearce and his act Death In June, connected in the mid 1980s, amongst them Tony Wakeford (Sol Invictus), David Tibet (Current 93), and Boyd Rice (NON), as well as Ian Read of Tony Wakeford's band, Sol Invictus, who later founded his own act, Fire and Ice. (Cf. Christian Dornbusch, "Von Landsertrommeln und Lärmorgien. Death In June und Kollaborateure," in Ästhetische Mobilmachung. Dark Wave, Neofolk und Industrial im Spannungsfeld rechter Ideologien, ed. Andreas Speit (Hamburg/Münster: Unrast Verlag, 2002), 147).

171 Cf. Gardell, Gods of the Blood, 296; François, "The Euro-Pagan Scene," 38; Andreas Speit, ed. Ästhetische Mobilmachung. Dark Wave, Neofolk und Industrial im Spannungsfeld rechter Ideologien (Hamburg/Münster: Unrast Verlag, 2002), 11; Shekhovtsov, "Apoliteic Music," 441f; Kennet Granholm, “'Sons of Northern Darkness.' Heathen Influences in Black Metal and Neofolk Music," Numen 58 (2011), 531-534.

172 Cf. Diesel and Gerten, Looking for Europe, 125.

173 Ibid., 112 .

174 Ibid., 119 .

175 Ibid., 236 . 
the album Island (1991) - a production for which Tibet's and Hilmar Örn's friend, the famous Icelandic singer Björk, provided backing vocals. ${ }^{176}$

As the links between Moynihan and Gerhard Petak have already shown, these musico-religious collaborations extended as far as central Europe as well. In this context, the activities of German musician Markus Wolff, from Waldteufel, are important. Wolff lives in the United States and has been actively transferring information from the German(ic) Faith scene to English-speaking audiences, not only through his music, but also through articles in Tyr ${ }^{177}$ and in the journal Vor Tru, of the ethnicist Asatru Alliance. ${ }^{178}$ Michael Moynihan, of Blood Axis, is a prominent Asatruer who is involved in the occultist and lefthand path' (i.e., Satanist) community, as well as in neofolk, in a myriad of ways: as a musician, writer, and owner of his own label and publishing series. ${ }^{179}$

We can preliminarily conclude that the parts of the neofolk scene which have been connected to Asatru milieus can be mainly, but not exclusively, found around the groups that take a decidedly ethnicist or racial-religious approach to Asatru and/or are actively interested in Ariosophic and occult aspects of the religion as well as in 'Satanism.' Most prominent among them are the Rune Gild, the Asatru Alliance, the Odinic Rite, and, to a certain degree, the Asatru Folk Assembly. Neofolk's take on Asatru is reflected in the content which these bands spread in word and image, and which they share with black, Viking, and Pagan metal, namely a combination of nature mysticism, a fascination for war-imagery, fascist aesthetics, ${ }^{180}$ an aestheticized Social Darwinism,

176 Ibid., 66. Musical performances of seid and Galdr also appear in ex-Death In June member Patrick Leaga's records, not only through his collaboration with Freya Aswynn, but also through his marriage to Amodali, of Mother Destruction - a musician who understands her own music as part of her involvement with female mysteries and seid shamanism. (cf. ibid., 126f). Northern shamanism and witchcraft are interests she shares with another former member of the circle around Freya Aswynn and Ian Read, Andrea Haugen, alias Nebelhexe or Andréa Nebel. The German musician, painter, writer, and performance artist resides in Norway and has played in groups such as Aghast and Hagalaz Runedance, and considers it her "heritage and birthright to keep the faith and traditions of my Germanic ancestors alive." Chad Hensley, "Wails from a Haunted Winter. Interview with Aghast," in Esoterra. The Journal of Extreme Culture, ed. Chad Hensley (s.l.: Creation Books, 2011), 259. Cf. http://www.andreanebel.com/, last accessed September 02, 2014. See for example Wolff, "Ludwig Fahrenkrog and the Germanic Faith Community."

178 Diesel and Gerten, Looking for Europe, 428.

179 Cf. http://heathenharvest.org/2014/o2/25/harvest-history-month-pt-xii-an-interviewwith-michael-moynihan-between-birds-of-prey/, last accessed September 15, 2014.

180 One example is the band name Blood Axis which refers to the alliance between Hitler and Mussolini, the "axis Berlin-Rome." 
and the occultist traditionalism of Italian fascist philosopher Julius Evola $(1898-1974){ }^{181}$ one of the most revered authors of the neofolk scene next to Ernst Jünger and Friedrich Nietzsche. ${ }^{182}$ Entwined with the lionization of these authors are references to German Faith and Ariosophic ideas, protagonists, and works. 183

The use of völkisch, fascist, and Ariosophic imagery and ideology has earned the neofolk scene fierce political critique, especially from anti-fascist individuals and organizations within and without the subcultures of metal and dark wave. ${ }^{184}$ Most of these critical authors agree that the political intentions behind these projects are not outright National Socialist or fascist. Rather, they share a number of interests and values with the political or meta-political approach of the Conservative Revolution and the New Right. Less critical explorers of the neofolk scene advocate taking the music and its overall presentation in word and image seriously as an aesthetic, and not as a political program. Consequently, the ambiguities with which many of the artists surround their own production should be understood as a "legitimate strategy of obscuring" which creates an "ambiguous legibility."185

181 The term Sol Invictus is taken from Evola's hallowing of the Roman sun god.

182 For the role of these thinkers within the music scene see the article by Patrick Achermann in the appendix of Diesel and Gerten, Looking for Europe, $461-487$.

183 Illustrations by Fidus and Ludwig Fahrenkrog are used, for example, by the bands Strength Through Joy and Blood Axis. Cf. ibid., 135; Jan Raabe and Andreas Speit, "L'art du mal. Vom antibürgerlichen Gestus zur faschistoiden Ästhetik," in Ästhetische Mobilmachung. Dark Wave, Neofolk und Industrial im Spannungsfeld rechter Ideologien, ed. Andreas Speit (Hamburg/Münster: Unrast Verlag, 2002), 87, 92. In 2001, a number of Euro-Pagan bands contributed to a whole album honoring Herman Hendrich, which was produced to raise money for the Nibelungenhort e.V. Cf. ibid., 121. Furthermore, Blood Axis set to music a text by Jörg Lanz von Liebenfels,' about the 'electric' organs of the original Aryan Übermenschen in their song, Electricity. Their logo, the Kruckenkreuz, which can be read as a combination of two swastikas turning in different directions, is the same as that which Ariosophist Jörg Lanz von Liebenfels used for his Neutempler-Orden. Cf. ibid., 91; Diesel and Gerten, Looking for Europe, 177 .

184 The anthology by Speit, Ästhetische Mobilmachung, and the volume by Dornbusch and Killguss, Unheilige Allianzen, as well as the work by Stéphane François, La musique Europaïenne. Ethnographie politique d'une subculture de droite (Paris: L'Harmattan, 2006); "The Euro-Pagan Scene," and Shekhovtsov, "Apoliteic Music" are examples of outside, politically critical, or anti-fascist perspectives on Neofolk, while the activities of groups like Grufties gegen Rechts or bands like Goethes Erben bear witness to the anti-fascist engagement of insiders.

185 Diesel and Gerten, Looking for Europe, 25, cf. 105. 
It is true that an aesthetic product needs to be approached on its own terms. Many artists within the broader scene of 'dark' music indeed work with modernist artistic means, which deliberately leave their audiences in an ambiguous space: They are confronted with the uncertainty as to whether the display of totalitarian themes, Germany's "brown past," and the occult ${ }^{186}$ is meant as a provocation or subversion, or whether it is supposed to convey a deeper truth. Mattias Gardell characterizes this deliberate obscurity of the "Asatrú/Satanic underworld" as a projection of "different faces, [a] mix [of] seriousness with pose, and use [of] smoke screens and distorting mirrors to enact a Nietzschean masquerade."187

Anton Shekovtsov interprets this mix of fascist worldview and abstinence from calls to "outright violence," political parties, and "recruitment to any political tendency"188 in the framework of Roger Griffin's theory of post-war fascism. This "third form" of fascism, and its main theorists, Julius Evola and Armin Mohler, sought neither to establish political parties nor enter into an alliance with revolutionary ultra-nationalism. Instead, it chose a kind of "rightwing 'inner emigration" after 1945, in order to save the idea of "the true State, the hierarchical and organic State"189 in the era of the "interregnum" of the despised liberal democracy. These concepts of "interregnum" and apoliteia influenced the New Right's concept of metapolitics as well, along with its attempts to "modify the dominant political culture and make it more susceptible to a non-democratic mode of politics." 190

From a social scientific point of view, it might seem reductionist to view fascism in general to be predominantly a cultural phenomenon. Nevertheless, it remains useful to consider the cultural and aesthetic aspects of international fascism and the Conservative Revolution in order to understand the nature of some black metal and neofolk groups,' as well as some Heathens' apoliteic strategies. It might very well serve the purpose that Cornelia Klinger191 describes when she claims that the merit of modern aesthetics is the synthesis of a simultaneous orientation toward the past and toward modernity. It is a synthesis, an attempt at reconciliation which acts as a surrogate for material gratification and social emancipation or participation. It offers of a sense of totality, unity, and meaning, the yearning for which modernity excludes and

\footnotetext{
186 Ibid., 33-35.

187 Gardell, Gods of the Blood, 284.

188 Shekhovtsov, "Apoliteic Music," 432.

189 Julius Evola, quoted in ibid., 437.

190 Ibid., 438.

191 Klinger, Flucht Trost Revolte.
} 
illegitimizes. Klinger goes on to argue that fascism offers a dangerous answer to this most-important blind spot of modernity - dangerous, because it enables an adaption to modernity on the aesthetic level, while excluding social modernization and justifying social and economic inequality as eternal laws. She suggests that fascism should not be understood as a surrogate religion, because in modernity, religious elements are already aestheticized. Rather, she investigates the mechanisms at work within this kind of a totalitarian aesthetic, in which politics themselves are aestheticized, and where the artist becomes the perfect embodiment of the political leader. This is a logic pursued by Julius Langbehn, for example, who understands 'German' artists, such as Rembrandt and Dürer, as the perfect models for future educators and leaders of their people. In this sense, the invocation of an ancient past is not to be taken as a wish to return to it, but rather as an expression of the conviction that one's own values are eternal and thus directed at an ideal future. ${ }^{192}$

The aesthetic strategies found in neofolk can be understood as a return to such an ideologically ambiguous art-religious constellation. This thesis is supported by the fact that neofolk invokes exactly the protagonists of this formation, from Wagner and Nietzsche to Ernst Jünger, Ludwig Fahrenkrog, Fidus, Hermann Hendrich, and Ariosophy. Occasionally, the race-theoretical implications of völkisch religion are invoked as well. Ian Read, of the Odinic Rite and the Rune Gild, promotes his music as part of his esoteric rune magic activities. He relates this musico-religious activity directly to ancestry and genetic make up when he calls "folk music [a part of] our sacred way" which has "a deeper resonance for those of common European descent [as:] DNA will out, as it were."193

The musician and history of religions student, Joshua Gentzke, of the band Lux Interna (Inner Light), makes an elaborate and obscure argument; he emphasizes the difficulty of accessing the divine under the ambiguous "postapocalyptic" condition characterized by a simultaneous longing for the presence of god or the gods and the fact of the absence of gods in today's world. He claims:

In art forms which reflect this struggle, this struggle itself is happening. It is not merely an event and the representation of this event. Here, we are not on the terrain which one usually calls 'aesthetics.' For me, the creation of music which deals with these questions is a real participation in this struggle.

192 Ibid., 201-216.

193 Joshua Buckley, "The Saxon Songwriter. An Interview With Fire \& Ice's Ian Read," Tyr. Myth - Culture - Tradition 1 (2002), $164 \mathrm{f}$. 
This is certainly a most emphatic affirmation of the religious purpose of art, which consequently is granted a privileged place in the process of learning to be open and to nurture and protect a place that could make such a return of the divine possible. The "inner light" after which his band is named is thus to be understood in a religious way. "With creative work, we elevate life to a higher plane, gather and let shine the light which is hidden in the essence of the world in which we live."194

\section{Art-Religion - An Encompassing Paradigm?}

The last example illustrates once more that the aesthetic and creative processes, scholarship, (meta-)politics, and religion are closely interwoven in these holistic, postmodern varieties of Conservative Revolutionary, Germanic Neopagan, and völkisch art-religion. This network can mostly be found on the side of contemporary artists who continue the apoliteic approach of the Conservative Revolutionary or fascist avant-garde. Some of them have been influential in the development of international Asatru. This does not mean, however, that their musical productions have had resounding success among the majority of a-racist Asatruers, who seem to have as eclectic musical tastes as their non-Asatru contemporaries. However, the part of this music scene which has made the mainstream, in particular Scandinavian and Eastern European metal bands, have become important conveyors of elements of the discourse on Nordic myth, and of the constellation of Nordic art-religion to a broader international public.

The close examination of Asatruers involved in neofolk, and their affinities to racial thought or ethnic essentialism, points to a fundamental ambiguity that has plagued Nordic art-religion from its beginnings up until the present day. In all the transformations and disparate political alliances, some central problems connected with this constellation have remained rather constant:

194 All quotes: Joshua Gentzke in Diesel and Gerten, Looking for Europe, 457-459: "In Kunstformen, die dieses Ringen reflektieren, findet dieses Ringen selbst statt. Es handelt sich hier nicht bloß um ein Ereignis und die Darstellung dieses Ereignisses. Wir befinden uns hier nicht auf dem Terrain dessen, was man für gewöhnlich mit dem Begriff 'Ästhetik' bezeichnet. Für mich ist das Schaffen von Musik, die sich mit diesen Fragen auseinander setzt, eine tatsächliche Teilnahme an diesem Ringen." - "Mit schöpferischer Arbeit heben wir das Leben auf eine höhere Ebene, versammeln und lassen das Licht strahlen, das im Wesen der Welt, in der wir leben, verborgen liegt." 
(1) There is a tendency to connect myth, poetry, and art to seemingly stable entities anchored in a deep mythic past, such as nature, landscape, ethnicity, and race. (2) There is a tendency to see art and culture, as well as aesthetic proficiency, as expressions of deep völkisch essences, and not as evolving and transforming practices shaped in constant, contingent exchanges. (3) Finally, there is a tendency to focus on aesthetics as a kind of compensation for social and economic modernization.

These central problems, however, are not limited to constellations of Nordic art-religion. Rather, as the previous chapters have shown, they constitute the whole discourse on Nordic myth, as well as its surrounding discourses on ethnicity, religion, nature, gender, and scholarship. As theories about art-religion and modernism inform us, ${ }^{195}$ the argument can be turned around as well. Aesthetics play a key role in modern(ist) attempts at a renewal of the arts, as well as of society, politics, and religion. Taking this into perspective, the art-religious logic is relevant for all the facets of modern Asatru discussed in this book, its forerunners in Germanic Faith, and Ariosophy, as well as their sources of inspiration in social movements and academic theory. They are all suspended in the characteristic field of tension between essentialist mechanisms of exclusion and the experience of the free play of autonomous creativity.

We have seen that the creation of ritual discussed in Chapter 3 , which is so typical for modern alternative religions, is experienced as a genuinely aesthetic creativity and can entail more or less elaborate theories of the aesthetic. On one end of the spectrum, in racial-religious and ethnicist Asatru, we find imaginations of ritual as a means to re-create the nation or give the state a ritual foundation, as is the case with fascist or Conservative Revolutionary movements. On the other end, and mainly in a-racist Asatru, there is the contemporary variety of the aesthetic search for totality, unity, and meaning, which is ruled by a late-modern logic of taste and choice. ${ }^{196}$ Here, the aesthetic has moved from art into life in a thoroughly post-Nietzschean way, into a psychotherapeutic culture which projects the experience of religious ritual

195 For example, Klinger, Flucht Trost Revolte; Klaus Lichtblau, "Innerweltliche Erlösung vom Rationalen' oder 'Reich diabolischer Herrlichkeit'? Zum Verhältnis von Kunst und Religion bei Georg Simmel und Max Weber," in Kunst und Religion. Studien zur Kultursoziologie und Kulturgeschichte, ed. Richard Faber and Volker Krech (Würzburg: Königshausen \& Neumann, 1999); Roger Griffin, Modernism and Fascism. The Sense of a Beginning under Mussolini and Hitler (London: Palgrave Macmillan, 2007).

196 Cf. Klinger, Flucht Trost Revolte, 222-236. 
as a creative, aesthetic, and therapeutic process onto a pre-Christian romanticized past.

Aesthetic dimensions play a role in race theories and the ethnic and cultural essentialisms discussed in Chapter 4, just as they do for imaginations of polytheism and constructed oppositions of the Semitic versus the Indo-European (or Aryan) analyzed in Chapter 5. In most of these theories, the higher-valued races, ethnicities, cultures, and religions are imbued with the aura of creativity and the inclination toward artistic talent, or are at least seen as being more conducive to the development of aesthetic expression than their respective counterparts, 'the Jews,' 'Semites,' and 'Orientals.' As shown in Chapter 6, concepts of a nature religion or spirituality are highly dependent on the aestheticized modern view of nature that reaches its first climax in Romanticism. This applies equally to the models of gendered spirituality discussed in Chapter 7 . Women's and matriarchal spirituality are closely associated with specific forms of artistic expression. Prominent figures of the feminist and women's spirituality or the goddess movement, such as Heide Göttner-Abendroth, with her theories of a matriarchal aesthetic, ${ }^{197}$ and the Swedish-born British painter, Monica Sjöö, ${ }^{198}$ promote their religion in aesthetic terms, rejecting the modern divide between art and ritual. Theories of the Männerbund provide academic foundations for the aestheticization of the (military) state and war. In the mythopoetic men's movement, such aestheticism is shifted from the collective to the individual, but it is still characterized by aestheticized images of the warrior. And finally, the academic theories employed to reconstruct a preChristian Germanic or Nordic religion, which we considered in Chapter 8, are dependent on a methodology that dates back to Romanticism and is driven by aesthetic concerns. From Danish poet and antiquarian N.F.S. Grundtvig's attempts to re-create a broad vision of Norse myth to the 19th- and early 2othcentury theories of folklorists and historians of religions, a hermeneutics of a 'contemplation of the whole,' of 'poetic vision,' 'enthusiasm' (Begeisterung), and spiritual experience has constituted the preconditions for the understanding of religion as well as art. And, as I have argued, all attempts to reconstruct a pre-Christian Norse religion up until today ultimately have had to employ such aesthetic imaginations of wholeness and authenticity.

197 Heide Göttner-Abendroth, Die tanzende Göttin. Prinzipien einer matriarchalen Ästhetik, 5 . ed. (Munich: Frauenoffensive, 1991 [1982]); The Dancing Goddess. Principles of a Matriarchal Aesthetic, trans. Maureen T. Krause (Boston: Beacon Press, 1991).

198 Cf. Monica Sjöö and Barbara Mor, The Great Cosmic Mother. Rediscovering the Religion of the Earth (San Francisco: Harper Collins, 1987). 
The results of this last chapter on Nordic art-religion raise broader questions about the relation between ideas about Nordic or Germanic myth, literary and aesthetic movements, contemporary spirituality, and their shifting political functions. From this perspective, art-religion can indeed serve as a useful, all-encompassing paradigm for understanding Germanic Neopaganism and its ambiguous location in modern societies. 